Systematic Review

\title{
An Update of the Systematic Appraisal of the Accuracy and Utility of Discography in Chronic Spinal Pain
}

Laxmaiah Manchikanti, MD¹, Amol Soin, MD², Ramsin M. Benyamin, MD³, Vijay Singh, MD4, Frank JE Falco, MD ${ }^{5}$, Aaron K. Calodney, $\mathrm{MD}^{6}$, Vahid Grami, MD, MPH${ }^{7}$, and Joshua A. Hirsch, MD

From: ${ }^{1}$ Pain Management Center of Paducah, Paducah, $\mathrm{KY}$, and University of Louisville, Louisville, KY; ${ }^{2}$ Ohio Pain Clinic, Centerville, $\mathrm{OH} ;{ }^{3}$ Millennium Pain Center, Bloomington, IL, and University of Illinois, Urbana-Champaign, IL; ${ }^{4}$ Spine Pain Diagnostics Associates, Niagara, WI; ${ }^{5}$ Mid Atlantic Spine \& Pain Physicians, Newark, DE, and Temple University Hospital, Philadelphia, PA; ${ }^{6}$ Texas Spine and Joint Hospital, Tyler, TX;

${ }^{7}$ Geisinger Medical Center Interventional Pain Center Woodbine, Danville, PA; and ${ }^{8}$ Massachusetts General Hospital and Harvard Medical School, Boston, MA.

Additional author affiliations information on $\mathrm{P} 102$.

Address Correspondence: Laxmaiah Manchikanti, MD 2831 Lone Oak Road

Paducah, Kentucky 42003 E-mail: drlm@thepainmd.com

Conflict of Interest: $\mathrm{Dr}$. Manchikanti has provided limited consulting services to Semnur Pharmaceuticals, Incorporated, which is developing nonparticulate steroids. Dr. Benyamin is a consultant for Medtronic. Dr. Falco is a consultant for St. Jude Medical Inc. and Joimax Inc.

Dr. Calodney is a consultant for Medtronic, SI-Bone, Stryker,

Nevro, and APEX Biologix.

Dr. Hirsch is a consultant for Medtronic.

Manuscript received:01-05-2018 Accepted for publication: 02-08-2018

Free full manuscript: www.painphysicianjournal.com
Background: The intervertebral disc has been implicated as a major cause of chronic spinal pain based on clinical, basic science, and epidemiological research. There is, however, a lack of consensus regarding the diagnosis and treatment of intervertebral disc disorders. Based on controlled evaluations, lumbar intervertebral discs have been shown to be the source of chronic back pain without disc herniation in $26 \%$ to $39 \%$ of patients, and in $16 \%$ to $53 \%$ of patients with pain in the cervical spine. Lumbar cervical, and thoracic provocation discography, which includes disc stimulation and morphological evaluation, is often used to distinguish a painful disc from other potential sources of pain. Despite the extensive literature on point, intense debate continues about lumbar discography as a diagnostic tool.

Study Design: A systematic review of the diagnostic accuracy of lumbar, cervical, and thoracic provocation and analgesic discography literature.

Objective: To systematically assess and re-evaluate the diagnostic accuracy of lumbar, cervical, and thoracic discography.

Methods: The available literature on discography was reviewed. A methodological quality assessment of included studies was performed using the Quality Appraisal of Reliability Studies (QAREL) checklist. Only diagnostic accuracy studies meeting at least $50 \%$ of the designated inclusion criteria were included in the analysis.

To assess the level of evidence, a modified grading of qualitative evidence criteria was utilized, with grading of evidence into 5 categories from Level I to Level $V$ incorporating evidence obtained from multiple high quality diagnostic accuracy studies for Level I and opinion or consensus of a large group of clinicians and/or scientists for Level $\mathrm{V}$. Data sources included relevant literature identified through searches of PubMed and EMBASE from 1966 to June 2017, and manual searches of the bibliographies of known primary and review articles.

Results: Over 100 manuscripts were considered for inclusion. Of these, 8 studies met inclusion criteria for diagnostic accuracy and prevalence with 5 studies assessing lumbar provocation discography and 3 studies assessing cervical discography. The results showed variable prevalence from $16.9 \%$ to $26 \%$ for discogenic pain and $16.9 \%$ to $42 \%$ for internal disc disruption. The cervical discogenic pain prevalence ranged from $16 \%$ to $53 \%$. Based on methodological quality assessment criteria the strength of evidence for lumbar provocation discography is Level III and for cervical discogenic pain is Level IV.

Limitations: Despite multiple publications in the lumbar spine, value and validity of discography continues to be debated. In reference to cervical and thoracic discography, the available literature and value and validity continues to be low.

Conclusion: This systematic review illustrates that lumbar provocation discography performed according to the International Association for the Study of Pain (IASP) criteria may be a useful too for evaluating chronic lumbar discogenic pain. The evidence is weaker for cervical and nonexistent for thoracic discography.

Key words: Lumbar intervertebral disc, cervical intervertebral disc, thoracic intervertebral disc, discography, provocation discography, analgesic discography, diagnostic accuracy, prevalence

Pain Physician 2018; 21: 91-110 


\subsection{INTRODUCTION}

The increasing socioeconomic burden imposed by chronic spinal pain, the resources utilized in managing chronic spinal pain with the growing number of modalities applied together with alleged low quality and the high cost of interventions has led to multiple negative health policy implications (1-35). Dieleman et al (5), in an assessment of US spending on personal health care and public health from 1996 to 2013, showed that the conditions with highest spending levels from 1966 to 2013 included low back and neck pain at the top, followed by diabetes. They also showed that in 2013, low back and neck pain accounted for the third highest amount, with estimated health care spending of $\$ 87.6$ billion; however, for overall musculoskeletal disorders the spending was $\$ 183.5$ billion. These expenditures correlate well with other previous estimations by Martin et al $(6,7)$ and Gaskin and Richard (10). The intervertebral discs, the zygapophysial (facet) joints, and sacroiliac joints have all been demonstrated, with controlled diagnostic techniques, to be common causes of chronic spinal pain $(1,34-71)$. However, there continues to be significant debate in reference to accuracy and clinical utility of multiple diagnostic techniques applied in interventional pain management $(1,34-71)$. Based on these evaluations, discogenic low back pain, with or without internal disc derangement, is estimated to affect between $16.9 \%$ and $39 \%$ of chronic low back pain sufferers without radicular symptoms $(47,50-55)$, $16 \%$ to $53 \%$ of patients with chronic pain in the cervical spine (58-60), and without estimated prevalence in the thoracic spine $(61,62)$. The intervertebral disc has been implicated as a source of spinal pain based on decades of pre-clinical, clinical, and epidemiological research, though the precise mechanisms continue to be debated as the literature evolves $(1,34-44,50-87)$. The intervertebral disc is responsible for causation of pain by means of disc herniation or without disc herniation. Disc herniation has been well described in the literature. However, the pain emanating from pathologic changes within the disc itself, without disc herniation $(1,34,35,88-99)$, was described before the classic description of disc herniation. Mixter and Barr described lumbar discectomy in 1934 (100). Thus, chronic spinal pain with or without extremity pain from an intervertebral disc has been described with 2 inter-related, but distinct etiologies, namely disc herniation and discogenic pain. Discogenic pain without disc herniation is variably termed discogenic pain, internal disc disruption, and painful degenerative disc disease $(1,34-41,44,50-57)$. Despite numerous advances in outcomes assessment, diagnosis based on history, physical exam, and radiological imaging has low sensitivity and specificity in determining whether or not the disc is a primary source of spinal pain $(1,34,35,37-41,48-73,100-120)$.

Hancock et al (38) performed a systematic review with inclusion of 28 studies, evaluating the ability of different diagnostic modalities to identify the disc as the source of low back pain. They showed that, in the majority of studies, various features observed on magnetic resonance imaging (MRI) (i.e., high-intensity zone, endplate changes, and disc degeneration) provided information that increased the probability of the disc being the source of low back pain. However, centralization was the only clinical feature found to increase the likelihood of the disc being the primary source of pain $(111,112)$. The absence of degeneration on MRI was the only test found to reduce the likelihood of the disc being the source of pain (111). The authors also found that the presence of a high-intensity zone significantly increased the probability of the disc(s) being a source of pain. However, a negative test does not meaningfully reduce the chances of the disc(s) being the pain generator. Clinical examination of a patient presenting with discogenic pain with inclusion of multiple provocative maneuvers has been helpful in identifying patients with potential discogenic pain, even though accurate diagnosis of discogenic pain may not be achieved $(111,112)$. However, multiple studies also based the diagnostic accuracy on provocation discography, another invasive modality which continues to face substantial controversy. The difficulty faced with physical examination is related to the fact that patients with facet joint pain and discogenic pain may present with somewhat of a similar clinical picture (1). Multiple investigators $(111,112)$ have shown centralization during repeated movements as a highly specific feature for positive discography; however, the overall sensitivity of this finding was low and there was reduced specificity when either severe disability or psychological distress was present.

MRI is known to provide exquisite anatomic detail facilitating surgical interventions. However, its use in discogenic pain has been described not only to have little value, but have an adverse effect by identifying incidental findings, leading to multiple unnecessary diagnostic and variable findings (117-119). Even though, there is significant importance provided to the high-intensity zone on MRI suggesting a highly specific marker of a painful lumbar disc, these findings are debatable. 
The other diagnostic modality commonly utilized in the diagnosis of discogenic pain is provocation discography. Provocation discography is the most specific procedure to diagnose discogenic low back pain; however, its accuracy has been reported to be low or at best unknown $(34,36,37,42,101)$. Bogduk et al $(36)$, in a comprehensive review of provocation discography, provided an anatomic and physiological basis for the procedure. In addition, they dispelled the null hypothesis that has been raised against the concept of discogenic pain and its diagnosis. They refuted multiple arguments raised that discs cannot and do not hurt, there is no discogenic pathology, and discogenic pain cannot be diagnosed or doing so is not clinically useful. In fact, Ohtori et al (120) provided the pathomechanism of discogenic low back pain in human and animal models, and clues about the pathomechanisms of discogenic low back pain with a confluence of biomedical and psychosocial factors including innervation, inflammation, and mechanical hypermobility, in conjunction with multiple biopsychosocial factors.

In a systematic review of lumbar discography as a diagnostic test for chronic low back pain (39), based on modified U.S. Preventive Services Task Force (USPSTF) level of evidence criteria, Manchikanti et al reported the strength of evidence was fair for the diagnostic accuracy of lumbar provocation discography utilizing International Association for the Study of Pain (IASP) criteria (121), limited for cervical discogenic pain (40); and no evidence for thoracic discography (41). Based on this systematic review, the authors (39) recommended that lumbar provocation discography performed according to IASP criteria may be a useful tool for evaluating chronic lumbar discogenic pain, but provided a limited recommendation for cervical and thoracic discography $(40,41)$.

When discography is combined with pain provocation and analgesia, its diagnostic capabilities are considered superior to the single dimensional tools (50-53,74,122-130). However, others insist, rather vigorously, that discography fails to improve diagnostic capabilities (131-143). Furthermore, there is ongoing debate regarding the gold standard evaluation of discogenic pain $(52,140,141)$, and the conservative, minimally invasive, and surgical management of discogenic pain $(1,34,36,37,42,57,101,141-143)$.

The purpose of this review is to systematically evaluate the diagnostic accuracy of discography utilizing provocation or analgesia, determine its applicability in clinical practice identifying deficiencies in the available evidence, and to describe implications for clinical prac- tice and further research in this area. This systematic review is an update of previously published systematic reviews (39-41).

\subsection{Methods}

The IASP criteria (121) for discogenic pain includes reproduction of a patient's typical pain with disc stimulation, while injection of 2 adjacent intervertebral discs fails to provoke pain. In addition, the pain cannot be ascribed to some other source innervated by the same segments that innervate the putatively symptomatic disc.

The degree of relief following local anesthetic injected into one or more discs is, theoretically, a more robust method to determine the degree to which the discs are contributing to the patient's symptoms (122). Thus, combining local anesthetic in equal concentration with contrast media injected into one or more discs during provocation discography confirms a positive provocative response and estimates the degree of pain caused by the one or more discs injected. Mixing local anesthetic with contrast is less traumatic than functional anesthetic discography, which requires using a large bore needle to enable the insertion of a catheter $(122,123,144-146)$. Although the addition of local anesthetic to all injected discs cannot always distinguish symptomatic from asymptomatic discs, the degree of post-procedure relief experienced may help assuage concerns of false-positive responses $(41,126,127,130,144-148)$.

\subsection{Criteria for Considering Studies for the Review}

\subsubsection{Types of Studies}

Diagnostic accuracy studies of lumbar, cervical, and thoracic discs provocation and/or analgesic discography.

\subsubsection{Types of Participants}

Participants of interest were adults aged at least 18 years with chronic spinal pain of at least 3 months duration.

\subsubsection{Types of Interventions}

The interventions were lumbar, cervical, and thoracic provocation and/or analgesic discography.

\subsubsection{Types of Outcome Measures}

- The primary outcome parameter was either pain provocation and/or pain relief with analgesic discography. 


\subsection{Literature Search}

Searches were performed from the following sources without language restrictions:

1. PubMed from 1966 www.ncbi.nlm.nih.gov/sites/entrez?db=pubmed

2. Cochrane Library www.thecochranelibrary.com/view/0/index.html

3. U.S. National Guideline Clearinghouse (NGC) www.guideline.gov/

4. Previous systematic reviews and cross references

5. Clinical Trials

clinicaltrials.gov/

The search period was from 1966 to August 2016.

\subsection{Search Strategy}

The search strategy emphasized chronic spinal pain and diagnostic interventional techniques with special emphasis on provocation and/or analgesic discography.

The search criteria is as follows:

\subsection{Data Collection and Analysis}

This systematic review focused only on invasive diagnostic studies, provocation and analgesic discography. The population of interest was patients suffering from chronic spinal pain, with or without extremity pain, for at least 3 months. Only the diagnostic accuracy of discography studies with or without prevalence estimates of chronic spinal pain were evaluated. Reports without appropriate diagnosis, non-systematic reviews, book chapters, and case reports were excluded.

\subsubsection{Inclusion and Exclusion Criteria}

Only studies utilizing controlled discography with IASP standards or analgesic discography were utilized or were included.

Only the studies with appropriate assessment and statistical evaluation were utilized.

\subsubsection{Data Extraction \& Management}

Two review authors independently, in an unblinded standardized manner, developed search criteria, searched for relevant literature, selected the manuscripts and extracted the data from the included studies. Disagreements were resolved by discussion between the 2 reviewers; if no consensus could be reached, a third author was called in to break the impasse. Data were analyzed separately based on whether the intervention was provocative or analgesic.
Methodological quality assessment was performed by the review authors. The assessment was carried out independently, in an unblinded standardized manner to assess the methodological quality and internal validity of all the studies considered for inclusion. The methodological quality assessment was performed in a manner to avoid any discrepancies, which were evaluated by a third reviewer and settled by consensus. Continued issues were also discussed with the entire group and resolved.

If there was conflict of interest with a reviewed manuscript (concerning authorship), if the reviewer was also one of the authors or had any type of conflict, the involved authors did not review the manuscript for methodological quality assessment.

\subsubsection{Methodological Quality or Validity Assessment}

The quality of each individual article used in this assessment was assessed using the Quality Appraisal of Reliability Studies (QAREL) checklist (Table 1) $(149,150)$. Each study in the final sample of eligible manuscripts was assessed using the 12-item checklist designed to assess quality and applicability. The face validity of this checklist was established by consultation with methodology experts $(149,150)$ and comparison with similar checklists used in other systematic reviews examining diagnostic reliability $(1,25,26,39-41,149,150)$. This checklist was also developed in accordance with the Standards for the Reporting Studies of Diagnostic Accuracy Studies (STARD) (151) and the Quality Assessment of Diagnostic Accuracy Studies (QUADAS) (152) appraisal tool. Studies were not given an overall numeric quality score; instead each item was considered separately and graded as "yes," "no," "unclear," or "not applicable."

Only diagnostic accuracy studies meeting at least $50 \%$ of applicable inclusion criteria were included for analysis. Studies scoring less than $50 \%$ are reported descriptively with critical analysis.

\subsection{Analysis of Evidence}

The analysis of the evidence was performed based on the American Society of Interventional Pain Physicians' (ASIPP) modification of multiple available criteria including those of United States Preventive Task Force (USPSTF) criteria as illustrated in Table 2 (153). The analysis was conducted using 5 levels of evidence ranging from Level I to $\mathrm{V}$.

At least 2 of the review authors independently, in an unblinded standardized manner, analyzed the evidence. Any disagreements between reviewers were 
Table 1. Quality Appraisal of Diagnostic Reliability (QAREL) checklist.

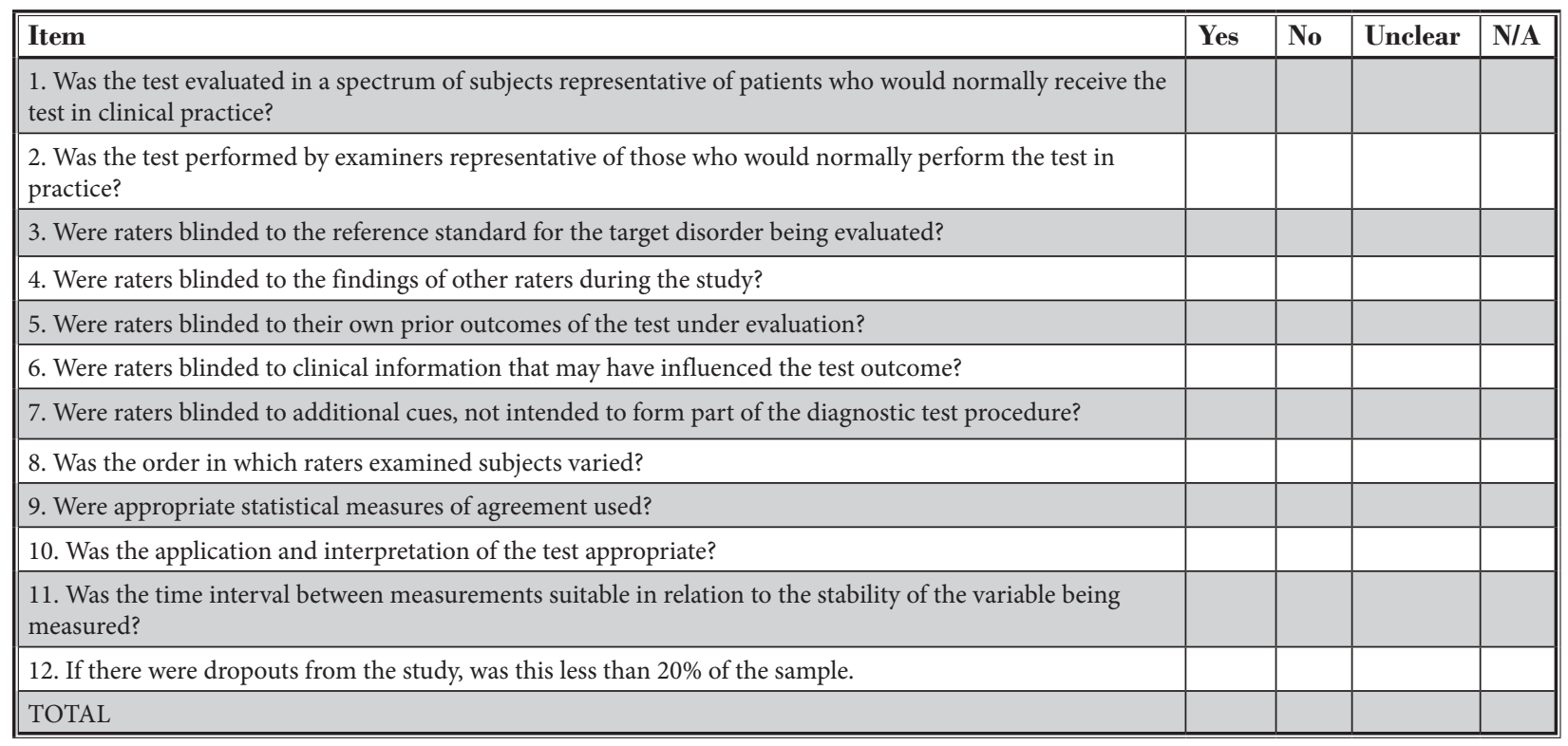

Lucas NP, Macaskill P, Irwing L, Bogduk N. The development of a quality appraisal tool for studies of diagnostic reliability (QAREL). J Clin Epidemiol 2010; 63:854-861 (150).

Table 2. Modified grading of qualitative evidence.

\begin{tabular}{|l|l||}
\hline Level I & $\begin{array}{l}\text { Evidence obtained from multiple relevant high quality randomized controlled trials } \\
\text { or } \\
\text { Evidence obtained from multiple high quality diagnostic accuracy studies }\end{array}$ \\
\hline Level II & $\begin{array}{l}\text { Evidence obtained from at least one relevant high quality randomized controlled trial or multiple relevant moderate or low } \\
\text { quality randomized controlled trials } \\
\text { or } \\
\text { Evidence obtained from at least one high quality diagnostic accuracy study or multiple moderate or low quality diagnostic } \\
\text { accuracy studies }\end{array}$ \\
\hline Level III & $\begin{array}{l}\text { Evidence obtained from at least one relevant moderate or low quality randomized controlled trial with multiple relevant } \\
\text { observational studies } \\
\text { or } \\
\text { Evidence obtained from at least one relevant high quality nonrandomized trial or observational study with multiple } \\
\text { moderate or low quality observational studies } \\
\text { or } \\
\text { Evidence obtained from at least one moderate quality diagnostic accuracy study in addition to low quality studies }\end{array}$ \\
\hline Level IV & $\begin{array}{l}\text { Evidence obtained from multiple moderate or low quality relevant observational studies } \\
\text { or } \\
\text { Evidence obtained from multiple relevant low quality diagnostic accuracy studies }\end{array}$ \\
\hline Level V & \begin{tabular}{l} 
Opinion or consensus of large group of clinicians and/or scientists \\
\hline
\end{tabular}
\end{tabular}

Source: Manchikanti L, et al. A modified approach to grading of evidence. Pain Physician 2014; 17:E319-E325 (153).

resolved by a third author and consensus. If there were any conflicts of interest (e.g., authorship), those reviewers were recused from assessment and analysis.

\subsection{Outcome of the Studies}

Outcome evaluations included the prevalence of lumbar discogenic pain and false-positive results.

\subsection{Results}

Figure 1 shows a flow diagram of study selection. There were 8 studies considered for inclusion $(47,51,52,54,55,58-60)$.

There were multiple studies of discography assessing accuracy, prevalence, and outcomes (30$34,50-53,55,58-62,70,71,72,110-113,126,130,131,133-$ $136,140,142,154-216)$. 


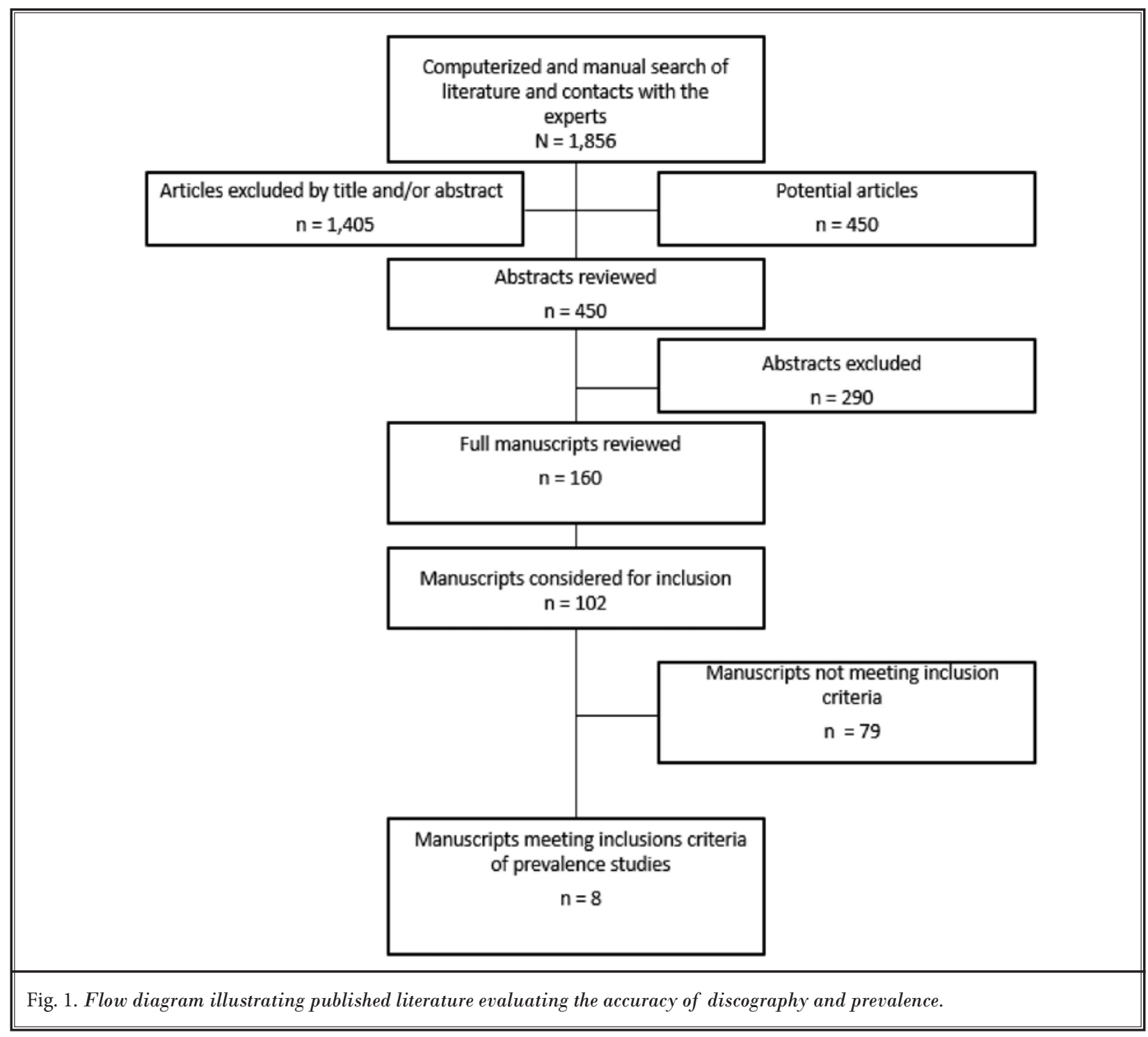

\subsection{Methodological Quality Assessment}

A methodological quality assessment of prevalence or diagnostic studies meeting inclusion criteria was carried out utilizing QAREL criteria as shown in Table 3. Studies achieving 4 of 12 or higher scores were included. Scores of 8 of 12 were considered to be high quality, 5 to 7 were considered to be moderate quality, and studies scoring less than 4 were considered to be of poor quality and excluded.

There were 8 studies assessing prevalence and which met inclusion criteria $(47,51,52,54,55,58-60)$.

\subsection{Diagnostic Studies of Prevalence}

Prevalence studies included 8 studies of which 5 described lumbar discogenic pain $(47,51,52,54,55)$ and 3 described cervical discogenic pain (58-60). There were no thoracic studies. There were 2 studies assessing the role of thoracic discography in the thoracic spine; however, they did not assess the prevalence $(61,62)$. All the included studies were shown to be of high quality. The studies of prevalence in lumbar discogenic pain showed variable prevalence of $26 \%$ (51), 39\% (52), $42 \%$ (54), $16.9 \%$ (47), and $21.8 \%$ (55) as shown in Table 4.

In the cervical spine, there were 3 studies by the same group of investigators (58-60) showing the prevalence to range from $16 \%$ (58) to $20 \%$ (59) to $53 \%$ (60) with a high variability. 


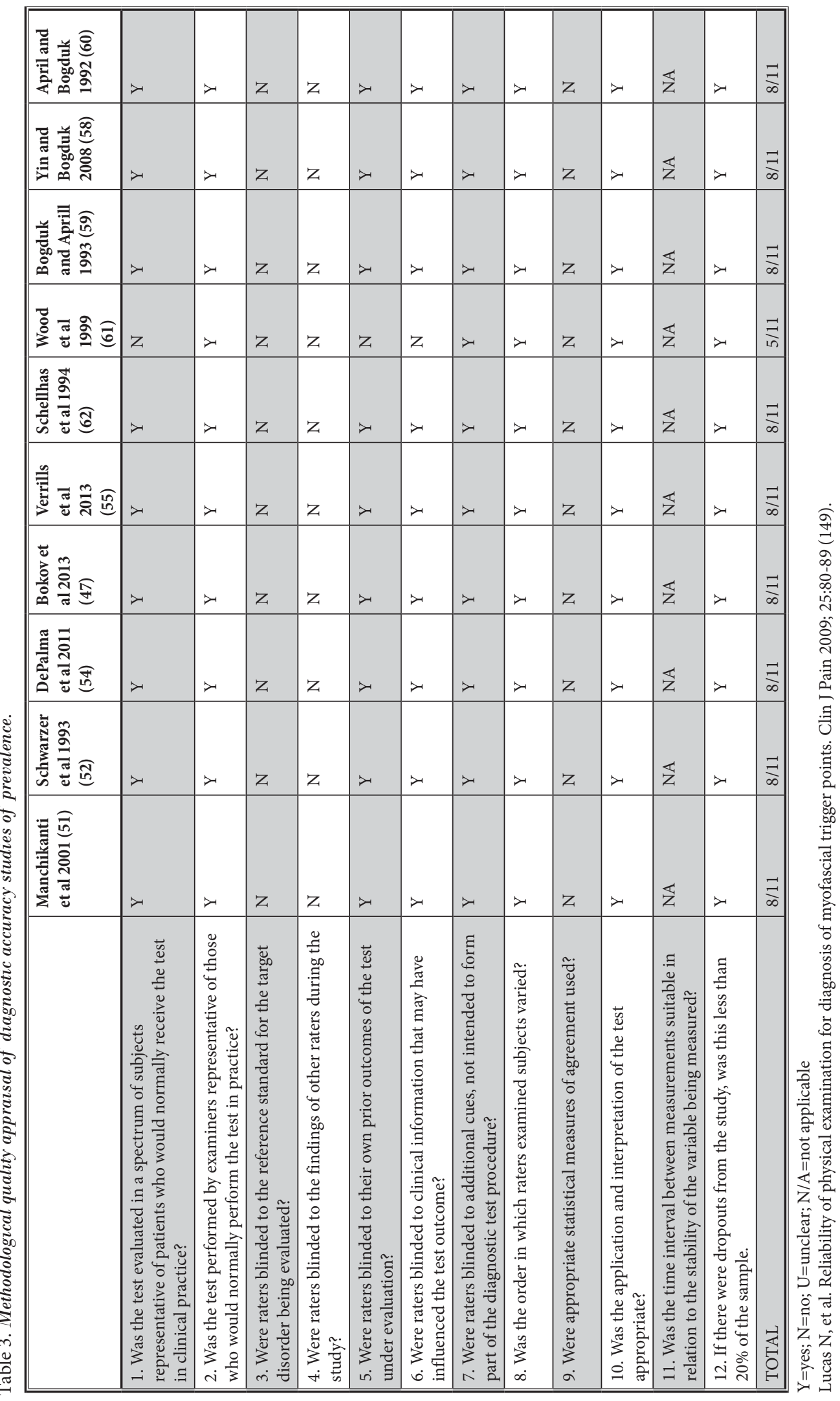




\subsection{Diagnostic Accuracy}

The number of studies available to assess the prevalence and diagnostic accuracy remained the same as in our previous review of lumbar discography (39). All of these studies assessed lumbar discogenic pain. Table 5 shows the characteristics and descriptions of prevalence and diagnostic accuracy studies of lumbar discography
$(47,51,52,54,55)$. Multiple others included anesthetic discography, subgroup analysis in 5 additional manuscripts, and confounding factors, which raise questions about the accuracy of diagnostic provocation discography (122-142).

The number of studies available assessing the diagnostic accuracy remained the same in cervical dis-

Table 4. Prevalence of discogenic pain utilizing IASP criteria.

\begin{tabular}{|c|c|c|c|}
\hline Study & $\begin{array}{l}\text { Methodological } \\
\text { Quality Scoring }\end{array}$ & Participants & Prevalence \\
\hline \multicolumn{4}{|l|}{ LUMBAR SPINE } \\
\hline $\begin{array}{l}\text { Manchikanti et al, } \\
2001 \text { (51) }\end{array}$ & $8 / 11$ & $\begin{array}{l}\text { From a group of } 120 \text { patients with low back pain, } \\
72 \text { patients negative for facet joint pain underwent } \\
\text { discography. }\end{array}$ & $\begin{array}{l}\text { The prevalence of discogenic pain was } \\
\text { established in } 26 \% \text { of total patient sample and } \\
43 \% \text { of patients negative for facet joint pain. }\end{array}$ \\
\hline $\begin{array}{l}\text { Schwarzer et al, } \\
1995(52)\end{array}$ & $8 / 11$ & $\begin{array}{l}92 \text { consecutive patients with chronic low back pain } \\
\text { and no history of previous lumbar surgery referred } \\
\text { for discography. }\end{array}$ & $\begin{array}{l}\text { The diagnostic criteria for internal disc } \\
\text { disruption were fully satisfied in } 39 \% \text { of the } \\
\text { patients, most commonly at L5/S1 and L4/5. }\end{array}$ \\
\hline $\begin{array}{l}\text { DePalma et al, } \\
2011(54)\end{array}$ & $8 / 11$ & $\begin{array}{l}\text { Of the } 156 \text { patients, } 71 \text { underwent provocation } \\
\text { discography. They also underwent other diagnostic } \\
\text { blocks including facet joint nerve blocks and } \\
\text { sacroiliac joint injections. }\end{array}$ & $\begin{array}{l}\text { The prevalence of internal disc disruption in } \\
\text { this study was } 42 \% \text {. }\end{array}$ \\
\hline $\begin{array}{l}\text { Bokov et al, } 2013 \\
(47)\end{array}$ & $8 / 11$ & $\begin{array}{l}\text { Authors evaluated } 83 \text { patients. Of these } 61 \text { patients } \\
\text { underwent discography with } 14 \text { of them showing } \\
\text { final positive results with a prevalence of } 16.9 \% \text {. }\end{array}$ & The prevalence of discogenic pain was $16.9 \%$. \\
\hline $\begin{array}{l}\text { Verrills et al, } 2015 \\
\text { (55) }\end{array}$ & $8 / 11$ & $\begin{array}{l}\text { In low back pain cases during the study of } 756 \text {, the } \\
\text { authors have evaluated } 223 \text { consecutive cases of } \\
\text { chronic low back pain with lumbar discography to } \\
\text { identify symptomatic and flanking asymptomatic } \\
\text { discs. In a subset of } 195 \text { patients receiving both } \\
\text { discography and diagnostic blocks, } 63 \% \text { had } \\
\text { proven discogenic pain. }\end{array}$ & $\begin{array}{l}\text { The prevalence of discogenic pain based on the } \\
\text { large sample of } 756 \text { was shown to be } 21.8 \% \text {. } \\
\text { This manuscript also showed a large percentage } \\
\text { of mixed etiology pain of } 18 \% \text {, with } 14 \% \\
\text { remaining undiagnosed, and } 63 \% \text { with proven } \\
\text { discogenic pain. }\end{array}$ \\
\hline \multicolumn{4}{|c|}{ CERVICAL SPINE } \\
\hline $\begin{array}{l}\text { Bogduk and } \\
\text { Aprill } 1993(59)\end{array}$ & $8 / 11$ & $\begin{array}{l}\text { The prevalence of disc pain and zygapophysial } \\
\text { joint pain occurring simultaneously in the same } \\
\text { segment of the neck, was determined in } 56 \text { patients } \\
\text { with post traumatic neck pain, with provocation } \\
\text { discography and cervical zygapophysial joints } \\
\text { blocks. }\end{array}$ & $\begin{array}{l}\text { The prevalence of discogenic pain was } 20 \% \\
\text { in the cervical spine, however, in combined } \\
\text { discogenic pain and zygapophysial joint pain } \\
\text { prevalence was } 41 \% \text {. }\end{array}$ \\
\hline $\begin{array}{l}\text { Yin and Bogduk } \\
2008(58)\end{array}$ & $8 / 11$ & $\begin{array}{l}\text { Authors in this study evaluated } 88 \text { patients } \\
\text { from a sample of } 167 \text { patients with provocative } \\
\text { discography and controlled zygapophysial joint } \\
\text { blocks. }\end{array}$ & $\begin{array}{l}\text { The prevalence of discogenic pain in } \\
\text { this sample was } 16 \% \text { with prevalence of } \\
\text { zygapophysial pain in } 55 \% \text { of the patients. }\end{array}$ \\
\hline $\begin{array}{l}\text { April and Bogduk } \\
1992(60)\end{array}$ & $8 / 11$ & $\begin{array}{l}\text { In this evaluation, prevalence of discogenic pain } \\
\text { was evaluated with provocation discography and } \\
\text { controlled cervical zygapophysial joint blocks in } \\
318 \text { consecutive patients. Provocation discography } \\
\text { was the sole investigation in } 152 \text { patients. In } \\
76 \text { patients, both provocation discography and } \\
\text { zygapophysial joint blocks were performed. }\end{array}$ & Overall prevalence of discogenic pain was $53 \%$. \\
\hline
\end{tabular}


Table 5. Characteristics of prevalence and diagnostic accuracy studies of lumbar discography.

\begin{tabular}{|c|c|c|c|}
\hline STUDY & PARTICIPANTS / RESULTS & AUTHORS' CONCLUSION & REVIEW CONCLUSION \\
\hline $\begin{array}{l}\text { Manchikanti et } \\
\text { al, } 2001 \text { (51) }\end{array}$ & $\begin{array}{l}120 \text { patients with a chief complaint of low back } \\
\text { pain were evaluated with precision diagnostic } \\
\text { injections, which included medial branch blocks, } \\
\text { provocative discography, and sacroiliac joint } \\
\text { injections. }\end{array}$ & $\begin{array}{l}\text { The facet joint is the most common } \\
\text { pain generator in chronic low back } \\
\text { pain, with identification of the facet } \\
\text { joint in } 40 \% \text { of patients, followed } \\
\text { by the disc in } 26 \% \text { of patients, and } \\
\text { the sacroiliac joint in only } 2 \% \text { of the } \\
\text { patients. }\end{array}$ & $\begin{array}{l}\text { Prevalence of discogenic pain } \\
\text { was present in } 26 \% \text { of the } \\
\text { sample. }\end{array}$ \\
\hline $\begin{array}{l}\text { Schwarzer et } \\
\text { al, } 1995 \text { (52) }\end{array}$ & $\begin{array}{l}92 \text { consecutive patients with chronic low back } \\
\text { pain and no history of previous lumbar surgery } \\
\text { were studied. Each patient underwent a standard } \\
\text { physical examination. Computed tomography } \\
\text { discography was performed at a minimum of } 2 \\
\text { levels. } \\
\text { Authors also used both discography and blocks } \\
\text { of the zygapophyseal joints. }\end{array}$ & $\begin{array}{l}\text { A diagnosis of internal disc disruption } \\
\text { can be made in a significant } \\
\text { proportion of patients with chronic } \\
\text { low back pain, but no conventional } \\
\text { clinical test can discriminate patients } \\
\text { with internal disc disruption from } \\
\text { patients with other conditions. } \\
\text { In patients with chronic low back } \\
\text { pain, the combination of discogenic } \\
\text { pain and zygapophysial joint pain is } \\
\text { uncommon. }\end{array}$ & $\begin{array}{l}\text { This study provided prevalence } \\
\text { of internal disc disruption. } \\
\text { This study provided } \\
\text { confirmation that combined } \\
\text { discogenic and facet joint pain } \\
\text { is rare. }\end{array}$ \\
\hline $\begin{array}{l}\text { DePalma et al, } \\
2011 \text { (54) }\end{array}$ & $\begin{array}{l}\text { A total of } 156 \text { patients underwent diagnostic } \\
\text { procedures including provocation discography, } \\
\text { dual diagnostic facet joint blocks, and sacroiliac } \\
\text { joint injections. All patients suffered with } \\
\text { chronic low back pain and failed conservative } \\
\text { management. Positive discography was defined } \\
\text { as concordant or partial concordant low back } \\
\text { pain above } 6 \text { or } 10 \text { at low pressure (below } 50 \text { psi) } \\
\text { over opening pressure due to Grade III or higher } \\
\text { annular tears. } \\
71 \text { patients underwent provocation discography } \\
\text { with a prevalence of } 41.8 \% \text {. }\end{array}$ & $\begin{array}{l}\text { The authors concluded that the } \\
\text { prevalence of internal disc disruption } \\
\text { was present in } 42 \% \text { of the patients. } \\
\text { Patients with internal disc disruption } \\
\text { were significantly younger than those } \\
\text { with facet joint pain or sacroiliac joint } \\
\text { pain. Increased age was associated } \\
\text { with a definitive probability of } \\
\text { internal disc disruption and increased } \\
\text { probability of facet joint pain and } \\
\text { sacroiliac joint pain. }\end{array}$ & $\begin{array}{l}\text { Well-performed evaluation } \\
\text { in a group of patients with } \\
\text { chronic low back pain yielding } \\
\text { a prevalence of internal disc } \\
\text { disruption of } 42 \% \text {. }\end{array}$ \\
\hline $\begin{array}{l}\text { Bokov et al, } \\
2013 \text { (47) }\end{array}$ & $\begin{array}{l}\text { The authors evaluated } 83 \text { patients. Of these, } 61 \\
\text { patients underwent discography with } 25 \text { of them } \\
\text { showing positive results. } 11 \text { patients or } 44 \% \text { of } \\
\text { these failed to respond to nucleoplasty. }\end{array}$ & $\begin{array}{l}\text { The authors concluded that in } \\
\text { choosing diagnostic criteria, not } \\
\text { only should the success rate of a } \\
\text { particular technology be taken into } \\
\text { consideration, but also the rate of } \\
\text { false-negative results. Consequently, } \\
\text { acceptable diagnostic criteria should } \\
\text { be based on a rational balance of } \\
\text { sensitivity and specificity. }\end{array}$ & $\begin{array}{l}\text { Based on the assessment of } \\
25 \text { of the } 61 \text { patients with the } \\
\text { concordant elicitation of pain, } \\
\text { the prevalence is estimated to } \\
\text { be } 40.98 \% \text {; however, the authors } \\
\text { of this manuscript have made } \\
\text { the argument, due to failure of } \\
\text { response to nucleoplasty, they } \\
\text { were considered as negative, } \\
\text { leading to a prevalence of } \\
\text { discogenic pain of } 16.9 \% \text {. }\end{array}$ \\
\hline $\begin{array}{l}\text { Verrills et al, } \\
2015 \text { (55) }\end{array}$ & $\begin{array}{l}\text { In this prospective, } 3 \text {-year study of } 223 \\
\text { consecutive cases of chronic low back pain, } \\
\text { lumbar discography was used to identify } \\
\text { symptomatic and flanking asymptomatic } \\
\text { discs. A subset of patients }(\mathrm{N}=195) \text { had } \\
\text { previously undergone posterior column blocks } \\
\text { to investigate spinal facet and/or sacroiliac } \\
\text { joints as contributing pain sources. The testing } \\
\text { of } 644 \text { discs showed positive discograms in } \\
74 \% \text { of patients, with } 22.9 \% \text { negative and } 3.1 \% \\
\text { as indeterminate. Taking into account all low } \\
\text { back pain cases during this study }(\mathrm{N}=756), \\
\text { discogenic pain prevalence was } 21.8 \% \text {. }\end{array}$ & $\begin{array}{l}\text { The authors concluded that prevalence } \\
\text { of discogenic pain in their community } \\
\text { practice was below the range, but } \\
\text { within confidence intervals, previously } \\
\text { reported levels of } 26 \% \text { to } 42 \% \text {. They } \\
\text { showed prevalence of discogenic pain } \\
\text { of } 21 \% \text { and they commented that in } \\
\text { well selected patients, discography } \\
\text { enabled a firm diagnosis and they } \\
\text { hypothesized that it would be found in } \\
\text { a higher proportion of patients. }\end{array}$ & $\begin{array}{l}\text { The prevalence of discogenic } \\
\text { pain as determined by the } \\
\text { authors is } 21.8 \% \text {, well within } \\
\text { the limits of other assessments. } \\
\text { However, in highly selected } \\
\text { patients discogenic pain is higher } \\
\text { with } 34 \% \text { in this study or it could } \\
\text { be projected as high as } 74 \% \text {. This } \\
\text { study emphasizes the importance } \\
\text { of prevalence calculations in } \\
\text { highly selected patients and } \\
\text { also assessing them in a larger } \\
\text { sample. }\end{array}$ \\
\hline
\end{tabular}


cography also (40). Table 6 shows the characteristics and descriptions of prevalence and diagnostic accuracy studies of cervical discography (58-60).

\subsection{Analysis of Evidence}

Based on the available evidence the prevalence of lumbar discogenic pain appears to range from $16.9 \%$ to $26 \%$ in patients with discogenic pain and $16.9 \%$ to $42 \%$ in patients with internal disc disruption.

The strength of evidence is Level 3 due to various inconsistencies among the studies and diagnostic accuracy of lumbar discography.
Prevalence of cervical discogenic pain is determined to be $16 \%$ to $53 \%$ with multiple internal inconsistencies. Consequently, the level of evidence is 4 based on the lack of significant diagnostic accuracy of cervical discography and the prevalence studies.

\subsection{Discussion}

This systematic review of cervical, thoracic, and lumbar discography shows Level 3 evidence for the prevalence and accuracy of lumbar provocation discography and Level 4 evidence for cervical provocation discography based on diagnostic accuracy studies, prev-

Table 6. Characteristics of prevalence and diagnostic accuracy studies of cervical discography.

\begin{tabular}{|c|c|c|c|c|}
\hline Study & $\begin{array}{l}\text { Patients and } \\
\text { Interventions }\end{array}$ & Results & Comments & Summary of Results \\
\hline $\begin{array}{l}\text { Bogduk and } \\
\text { Aprill } 1993 \text { (59) }\end{array}$ & $\begin{array}{l}\text { To determine the } \\
\text { prevalence of disc pain and } \\
\text { zygapophysial joint pain } \\
\text { occurring simultaneously } \\
\text { in the same segment of } \\
\text { the neck, } 56 \text { patients with } \\
\text { post traumatic neck pain } \\
\text { underwent both provocation } \\
\text { discography and cervical } \\
\text { zygapophysial joint blocks. }\end{array}$ & $\begin{array}{l}\text { Both a symptomatic } \\
\text { disc and a symptomatic } \\
\text { zygapophysial joint were } \\
\text { identified in the same } \\
\text { segment in } 41 \% \text { of the } \\
\text { patients. Discs alone were } \\
\text { symptomatic in only } 20 \% \\
\text { of the sample. }\end{array}$ & $\begin{array}{l}\text { Authors indicated that the } \\
\text { investigation of neck pain } \\
\text { by discography alone or by } \\
\text { zygapophysial blocks alone } \\
\text { constitute an inadequate } \\
\text { approach to neck pain } \\
\text { which fails to identify the } \\
\text { majority of patients whose } \\
\text { symptoms stem from } \\
\text { multiple elements in the } 3 \\
\text { joint complexes of the neck. }\end{array}$ & $\begin{array}{l}\text { Since provocation discography was } \\
\text { positive along with a zygapophysial } \\
\text { joint block in } 41 \% \text { of the patients } \\
\text { and discs were positive alone in } 20 \% \\
\text { of the sample, a high prevalence } \\
\text { of } 61 \% \text { may be the final result of } \\
\text { discogenic pain in the cervical spine. } \\
\text { In addition, } 35 \% \text { of the patients did } \\
\text { not undergo any investigations. } \\
\text { Authors also postulated that } \\
\text { if cervical segments are fully } \\
\text { investigated it emerges that cervical } \\
\text { discs are not the most common, } \\
\text { primary source of neck pain. }\end{array}$ \\
\hline $\begin{array}{l}\text { Yin and Bogduk } \\
2008 \text { (58) }\end{array}$ & $\begin{array}{l}\text { This evaluation was } \\
\text { undertaken to determine } \\
\text { the prevalence of different } \\
\text { cause of neck pain in a } \\
\text { private practice clinic. } \\
\text { Overall } 88 \text { patients were } \\
\text { evaluated from a sample of } \\
167 \text { patients with } 46 \% \text { of } \\
\text { the patients completing the } \\
\text { investigations. }\end{array}$ & $\begin{array}{l}\text { A large proportion of } \\
\text { patients did not pursue } \\
\text { investigations. Among } \\
\text { the } 46 \% \text { of patients who } \\
\text { completed investigations, } \\
\text { the prevalence of } \\
\text { discogenic pain was } 16 \% \\
\text { and the prevalence of } \\
\text { zygapophysial joint pain } \\
\text { was 55\% with diagnosis } \\
\text { remaining elusive in 32\% } \\
\text { of those patients who } \\
\text { completed investigations. }\end{array}$ & $\begin{array}{l}\text { In a private practice } \\
\text { setting, authors were able } \\
\text { to complete investigation } \\
\text { in less than } 50 \% \text { of the } \\
\text { patients; however, in } \\
\text { patients who completed } \\
\text { controlled blocks or more } \\
\text { than one invasive test, a } \\
\text { pathoanatomic diagnosis } \\
\text { remained elusive in only } \\
17 \% \text {. }\end{array}$ & $\begin{array}{l}\text { Authors described that this study } \\
\text { was not designed to establish } \\
\text { the prevalence of various causes } \\
\text { of neck pain in the general } \\
\text { community, or even a particular } \\
\text { sample of that community. The } \\
\text { prevalence was estimated in a } \\
\text { private pain clinic with highly } \\
\text { select group of patients. This } \\
\text { study provided prevalence of } \\
\text { discogenic pain in } 16 \% \text { of the } \\
\text { patients even though a large } \\
\text { proportion of the patients did } \\
\text { not undergo the assessment. }\end{array}$ \\
\hline $\begin{array}{l}\text { Aprill and } \\
\text { Bogduk, } 1992 \\
(60)\end{array}$ & $\begin{array}{l}\text { This study evaluated prevalence } \\
\text { of cervical zygapophysial joint } \\
\text { pain in } 318 \text { consecutive patients } \\
\text { with intractable neck pain } \\
\text { who underwent provocation } \\
\text { discography and cervical } \\
\text { zygapophysial joint blocks. } \\
\text { Provocation discography was the } \\
\text { sole investigation in } 152 \text { patients. } \\
\text { In } 76 \text { patients, both provocation } \\
\text { discography and zygapophysial } \\
\text { joint blocks were performed. }\end{array}$ & $\begin{array}{l}\text { Provocation discography } \\
\text { provided unambiguous } \\
\text { information and was } \\
\text { the sole investigation } \\
\text { performed in } 152 \\
\text { patients, in } 127 \text { of whom } \\
\text { a symptomatic disc was } \\
\text { found at one or more } \\
\text { levels, whereas in } 25 \\
\text { patients provocation } \\
\text { discography was negative } \\
\text { at the levels investigated. }\end{array}$ & $\begin{array}{l}\text { In the } 76 \text { patients } \\
\text { who underwent both } \\
\text { provocation discography } \\
\text { and zygapophysial joint } \\
\text { blocks, discography was } \\
\text { indeterminate in } 6 \text { patients, } \\
\text { and discography as well as } \\
\text { zygapophysial joint blocks } \\
\text { were both positive in } 26 \\
\text { patients and both negative } \\
\text { in } 12 \text {. }\end{array}$ & $\begin{array}{l}\text { Overall, in this study, } 53 \% \text { of the } \\
\text { sample suffered a symptomatic } \\
\text { disc. }\end{array}$ \\
\hline
\end{tabular}


alence studies, and outcomes assessment. Even though multiple studies are available assessing the reliability of diagnostic accuracy, there are multiple variables including lack of standardization, limitations in technique, the paucity of studies evaluating outcomes, and various reports contradicting the diagnostic accuracy of discography. Thus, the evidence for use of discography at any site prior to fusion appears to be limited at best. These results are similar to the previous results published by multiple authors $(36-42,44,45,68)$. This review included additional studies than previously included in systematic reviews; however, the results appear to be the same with no significant change. Consequently, diagnostic accuracy and false-positive rate assessment continues to be an issue of intense debate.

Carragee et al (131-140) have published multiple manuscripts questioning the value and validity of diagnostic provocation discography. Wolfer et al (57), in a systematic review and meta-analysis of lumbar provocation discography in asymptomatic participants, identified 11 studies meeting inclusion criteria for analysis and showed results contradictory to the opinions of Carragee et al (131-140). They combined all extractable data and arrived at a false-positive rate of $9.3 \%$ per patient and $6 \%$ per disc. Further analysis showed that data pooled from asymptomatic participants without low back pain or any confounding factors also showed a lower false-positive rate of $3 \%$ per patient and $2.1 \%$ per disc. They also analyzed chronic pain patients without low back pain and showed that the false-positive rate was $5.6 \%$ per patient and $3.85 \%$ per disc. Thus, Wolfer et al (57) concluded chronic pain does not appear to be a confounding factor and, patients with chronic pain possess the ability to distinguish between pathologic and nonpathologic discs, namely positive and negative discs. They also extensively analyzed other groups including those with iliac crest pain after bone grafting, chronic neck pain, somatization disorder, and post discectomy. They showed low false-positive rates in patients with iliac crest pain after bone grafting of $12 \%$ and $7.1 \%$, whereas, false-positive rates in patients with chronic neck pain was $0 \%$ compared to post discectomy patients $15 \%$ and $9.1 \%$, either per patient or per disc. However, they also showed a significantly high proportion of patients to be false-positive with somatization disorder with $50 \%$ per patient and $22.2 \%$ per disc. They were also unable to determine false-positive rates in patients with chronic back pain. The meta-analysis led them to recommend a more stringent, low-pressure positive criteria (< 15 PSI AOP), since it was associated with a low false-positive rate.
In addition, multiple reports by Carragee et al (131140 ) and several guidelines based on the available literature (217-223) have suggested that discography may in fact result in unnecessary surgery and accelerated disc degeneration in addition to misdiagnosis (210215). Much of the literature related to negative aspects of discography, as described earlier, is from Carragee et al (131-140,212-216). In a recent assessment of provocation discography causing clinically important injury to lumbar intervertebral disc (210), the authors concluded that the disc puncture and pressurized injection performed during provocative discography can increase the risk of clinical disc problems in exposed patients. The results of this study showed that at 10-year followup, there were 16 lumbar surgeries in the discography group compared with 4 in the control group. Further, medical visits, computed tomography (CT)/MRI examinations, work loss, and prolonged back pain episodes were all more frequent in the discography group compared with controlled participants. The study originally enrolled 71 discography patients and 72 controlled participants who completed the baseline evaluation. At 10-year follow-up, 57 discography and 53 controlled patients completed all surveillance evaluations at one, 2,5 , and 10 years after enrollment. In addition, cytotoxicity of local anesthetic and non-contrast agents on bovine intervertebral disc cells cultured in a 3-dimensional culture system has been reported (224). Further, influence of intradiscal medication or nucleus pulposus cells also has been described (225) with significant discount in cell counts. However, only a small decrease in cell viability was observed. An evaluation of cytokine in individuals with low back pain using discographic lavage concluded that potential inflammatory markers were elevated in degenerative discs, both positive and negative, emphasizing lack of value for discography (226). Thus, despite concordance of opinions in this respect, overall evidence for discography as a diagnostic test appears to be Level 3 . In the past we have shown moderate or fair evidence for lumbar provocation discography. Overall these results are similar to multiple previous reviews $(1,39,227)$.

The prevalence data and diagnostic accuracy of cervical discography seems to be with a lower level of evidence of 4 . This is based on substantial internal inconsistency among the few studies available. These results are also similar to our previous reviews $(1,40)$.

Provocation discography as a diagnostic test has faced substantial criticism. O'Neill (161) described all diagnostic tests for chronic low back pain as dismal. 
Others also have provided contradictory perspectives on the role of discography in surgical decision-making or the diagnosis itself $(131-140,162-168)$. A systematic review on the accuracy of tests for patient selection for spinal fusion for chronic low back pain by Willems et al (172) concluded that no subset of patients with chronic low back pain could be identified for whom spinal fusion is a predictable and effective treatment. They also opined that best evidence does not support the use of current tests for patient selection in clinical practice. In this analysis, they utilized 4 studies of provocation discography (170-173) prior to fusion resulting in the conclusion that discography has no significant value as a preoperative test prior to selection of lumbar fusion. In addition, advanced imaging continues to show failure to diagnose a painful disc from a painless disc as multiple abnormalities have been shown over the years $(228,229)$. Kallewaard et al (69) have also shown lack of transfer of pressure to adjacent discs during human low-pressure controlled discography, leading to the impression that the majority of the misimpressions were related to highpressure discography. In addition, multiple modalities of treatments have been published including those of epidural injections, which were shown to be superior to fusion in discogenic pain (99). Multiple intradiscal therapies $(30-33,175,230,231)$ have been advocated without definitive results thus far.

Despite less reliable evidence of diagnostic accuracy and prevalence studies in the cervical spine, surgical outcomes have been described in multiple studies $(39,185-202)$. The majority of these studies have been retrospective or observational with no randomized controlled trials. Thus, results instill very limited confidence and evidence is only empirical.

\subsection{Conclusion}

This systematic review illustrates that lumbar provocation discography performed according to IASP criteria may be a useful tool for evaluating chronic lumbar discogenic pain. Based on modified best evidence synthesis, the indicated strength of evidence was Level III for lumbar discography and Level IV for cervical dis- cography due to significant internal inconsistency in the lumbar spine and extremely high internal inconsistency in the cervical discography.

\section{Acknowledgments}

The authors wish to thank Vidyasagar Pampati, MSc, for statistical assistance; Bert Fellows, MA, Director Emeritus of Psychological Services, for manuscript review; and Tonie M. Hatton and Diane E. Neihoff, transcriptionists, for their assistance in preparation of this manuscript. We would like to thank the editorial board of Pain Physician for review and criticism in improving the manuscript.

\section{Author affiliation}

Dr. Manchikanti is Medical Director of the Pain Management Center of Paducah, Paducah, KY, and Clinical Professor, Anesthesiology and Perioperative Medicine, University of Louisville, Louisville, KY. Dr. Soin is Medical Director, Ohio Pain Clinic, Centerville, $\mathrm{OH}$ and Clinical Assistant Professor of Surgery at Wright State University, Dayton, OH. Dr. Benyamin is Medical Director, Millennium Pain Center, Bloomington, IL, and Clinical Assistant Professor of Surgery, College of Medicine, University of Illinois, Urbana-Champaign, IL. Dr. Singh is Medical Director, Spine Pain Diagnostics Associates, Niagara, WI Dr. Falco is Medical Director of Mid Atlantic Spine \& Pain Physicians, Newark, DE; Director, Pain Medicine Fellowship Program, Temple University Hospital, Philadelphia, PA; and Adjunct Associate Professor, Department of PM\&R, Temple University Medical School, Philadelphia, PA. Dr. Calodney is Director of Clinical Research, Precision Spine Care, Texas Spine and Joint Hospital, Tyler, TX. Dr. Grami is an Associate Physician in Pain Medicine and Anesthesiology at Geisinger Medical Center Interventional Pain Center Woodbine, Danville, PA. Dr. Hirsch is Vice Chief of Interventional Care, Chief of Neurolnterventional Spine, Service Line Chief of Interventional Radiology, Director Interventional and Endovascular Neuroradiology, Massachusetts General Hospital; Harvard Medical School, Boston, MA. 


\section{References}

1. Manchikanti L, Abdi S, Atluri S, Benyamin RM, Boswell MV, Buenaventura RM, Bryce DA, Burks PA, Caraway DL, Calodney AK, Cash KA, Christo PJ, Cohen SP, Colson J, Conn A, Cordner HJ, Coubarous S, Datta S, Deer TR, Diwan SA, Falco FJE, Fellows B, Geffert SC, Grider JS, Gupta S, Hameed H, Hameed M, Hansen $H$, Helm II S, Janata JW, Justiz R, Kaye AD, Lee $M$, Manchikanti $\mathrm{KN}$, McManus CD, Onyewu O, Parr AT, Patel VB, Racz GB, Sehgal N, Sharma M, Simopoulos TT, Singh V, Smith HS, Snook LT, Swicegood J, Vallejo R, Ward SP, Wargo BW, Zhu J, Hirsch JA. An update of comprehensive evidence-based guidelines for interventional techniques of chronic spinal pain: Part II: Guidance and recommendations. Pain Physician 2013; 16:S49-S283.

2. US Burden of Disease Collaborators. The state of US health, 1999-2010: Burden of diseases, injuries, and risk factors. JAMA 2013; 310:591-608.

3. Hoy D, March L, Brooks P, Blyth F, Woolf A, Bain C, Williams G, Smith E, Vos T, Barendregt J, Murray C, Burstein $\mathrm{R}$, Buchbinder R. The global burden of low back pain: Estimates from the Global Burden of Disease 2010 study. Ann Rheum Dis 2014; 73:968-974.

4. Hoy D, March L, Woolf A, Blyth F, Brooks P, Smith E, Vos T, Barendregt J, Blore J, Murray C, Burstein R, Buchbinder R. The global burden of neck pain: Estimates from the global burden of disease 2010 study. Ann Rheum Dis 2014; 73:1309-1315.

5. Dieleman JL, Baral R, Birger M, Bui AL, Bulchis A, Chapin A, Hamavid H, Horst C, Johnson EK, Joseph J, Lavado R, Lomsadze L, Reynolds A, Squires E, Campbell $M$, DeCenso $B$, Dicker $D$, Flaxman AD, Gabert R, Highfill T, Naghavi M, Nightingale N, Templin T, Tobias MI, Vos T, Murray CJ. US spending on personal health care and public health, 1996 - 2013. JAMA 2016; 316:2627-2646.

6. Martin BI, Turner JA, Mirza SK, Lee MJ, Comstock BA, Deyo RA. Trends in health care expenditures, utilization, and health status among US adults with spine problems, 1997-2006. Spine (Phila $\mathrm{Pa}$ 1976) 2009; 34:2077-2084.

7. Martin BI, Deyo RA, Mirza SK, Turner JA, Comstock BA, Hollingworth W, Sullivan SD. Expenditures and health status among adults with back and neck prob- lems. JAMA 2008; 299:656-664.

8. Ivanova JI, Birnbaum HG, Schiller M, Kantor E, Johnstone BM, Swindle RW. Real-world practice patterns, health-care utilization, and costs in patients with low back pain: The long road to guidelineconcordant care. Spine ] 2011; 11:622-632.

9. Rajaee SS, Bae HW, Kanim LE, Delamarter RB. Spinal fusion in the United States: Analysis of trends from 1998 to 2008. Spine (Phila Pa 1976) 2012; 37:67-76.

10. Gaskin DJ, Richard P. The economic costs of pain in the United States. J Pain 2012; 13:715-724.

11. Manchikanti L, Pampati V, Falco FJE, Hirsch JA. An updated assessment of utilization of interventional pain management techniques in the Medicare population: 2000 - 2013. Pain Physician 2015; 18:E115-E127.

12. Manchikanti L, Pampati V, Hirsch JA. Utilization of interventional techniques in managing chronic pain in Medicare population from 2000 to 2014: An analysis of patterns of utilization. Pain Physician 2016; 19: $E_{531}-E_{546}$

13. Manchikanti L, Hirsch JA, Pampati V, Boswell MV. Utilization of facet joint and sacroiliac joint interventions in Medicare population from 2000 to 2014: Explosive growth continues! Curr Pain Headache Rep 2016; 20:58.

14. Manchikanti L, Pampati V, Hirsch JA. Retrospective cohort study of usage patterns of epidural injections for spinal pain in the US fee-for-service Medicare population from 2000 to 2014. BMJ Open 2016; 6:e013042.

15. Hirsch JA, Chandra RV, Pampati V, Barr JD, Brook AL, Manchikanti L. Analysis of vertebral augmentation practice patterns: A 2016 update. J Neurointerv Surg 2016 Oct 31; [Epub ahead of print].

16. Manchikanti L, Hirsch JA. Neurological complications associated with epidural steroid injections. Curr Pain Headache Rep 2015; 19:482.

17. Deyo RA, Mirza SK, Martin BI, Kreuter W, Goodman DC, Jarvik JG. Trends, major medical complications, and charges associated with surgery for lumbar spinal stenosis in older adults. JAMA 2010; 303:1259-1265.

18. Manchikanti L, Helm $S$ 2nd, Benyamin RM, Hirsch JA. A critical analysis of Obamacare: Affordable care or insurance for many and coverage for few? Pain Phy- sician 2017; 20:111-138.

19. Manchikanti L, Helm II S, Benyamin RM, Hirsch JA. Merit-Based Incentive Payment System (MIPS): Harsh choices for interventional pain management physicians. Pain Physician 2016; 19:E917-E934.

20. Manchikanti L, Hammer M, Benyamin RM, Hirsch JA. Physician Quality Reporting System (PQRS) for interventional pain management practices: Challenges and opportunities. Pain Physician 2016; 19: E15-E32.

21. Hirsch JA, Leslie-Mazwi TM, Nicola GN, Bhargavan-Chatfield $M$, Seidenwurm DJ, Silva E, Manchikanti L. PQRS and the MACRA: Value-based payments have moved from concept to reality. AJNR Am J Neuroradiol 2016; 37:2195-2200.

22. Manchikanti L, Staats PS, Boswell MV, Hirsch JA. Analysis of the carrot and stick policy of repeal of the sustainable growth rate formula: The good, the bad, and the ugly. Pain Physician 2015; 18:E273-E292.

23. Hirsch JA, Leslie-Mazwi TM, Patel AB, Rabinov JD, Gonzalex RG, Barr RM, Nicola GN, Klucznik RP, Prestigiacomo C), Manchikanti L. MACRA: Background, opportunities and challenges for the neurointerventional specialist. J Neurointerv Surg 2016; 8:868-874.

24. Obama B. United States health care reform: Progress to date and next steps. JAMA 2016; 316:525-532.

25. Boswell MV, Manchikanti L, Kaye AD, Bakshi S, Gharibo CG, Gupta S, Jha S, Nampiaparampil DE, Simopoulos TT, Hirsch JA. A best-evidence systematic appraisal of the diagnostic accuracy and utility of facet (zygapophysial) joint injections in chronic spinal pain. Pain Physician 2015; 18: E497-E533.

26. Simopoulos TT, Manchikanti L, Gupta S, Aydin SM, Kim CH, Solanki D, Nampiaparampil DE, Singh V, Staats PS, Hirsch JA. Systematic review of the diagnostic accuracy and therapeutic effectiveness of sacroiliac joint interventions. Pain Physician 2015; 18:E713-E756.

27. Manchikanti L, Hirsch JA, Falco FJE, Boswell MF. Management of lumbar zygapophysial (facet) joint pain. World J Orthop 2016; 7:315-337.

28. Manchikanti L, Hirsch JA, Kaye AD, Boswell MV. Cervical zygapophysial (facet) joint pain: Effectiveness of intervention- 
al management strategies. Postgrad Med 2016; 128:54-68.

29. Bae HW, Rajaee SS, Kanim LE. Nationwide trends in the surgical management of lumbar spinal stenosis. Spine (Phila $\mathrm{Pa}$ 1976) 2013; 38:916-926.

30. Zhang X, Hao J, Hu Z, Yang H. Clinical evaluation and magnetic resonance imaging assessment of intradiscal methylene blue injection for the treatment of discogenic low back pain. Pain Physician 2016; 19:E1189-E1195.

31. Sainoh $T$, Orita $S$, Miyago $M$, Inoue G, Yamauchi K, Suzuki M, Sakuma Y, Kubota G, Oikawa Y, Inage K, Sato J, Nakata Y, Aoki Y, Takahashi K, Ohtori S. Single intradiscal injection of the interleukin-6 receptor antibody tocilizumab provides short-term relief of discogenic low back pain; prospective comparative cohort study. J Orthop Sci 2016; 21:2-6.

32. Yin W, Pauza K, Olan WJ, Doerzbacher JF, Thorne KJ. Intradiscal injection of fibrin sealant for the treatment of symptomatic lumbar internal disc disruption: Results of a prospective multicenter pilot study with 24-month follow-up. Pain Med 2014; 15:16-31.

33. Desai MJ, Kapural L, Petersohn JD, Vallejo R, Menzies R, Creamer M, Gofeld M. A prospective, randomized, multicenter, open-label clinical trial comparing intradiscal biacuplasty to conventional medical management for discogenic lumbar back pain. Spine (Phila Pa 1976) 2016; 41:1065-1074

34. Manchikanti L, Hirsch JA. An update on the management of chronic lumbar discogenic pain. Pain Manag 2015; 5:373-386.

35. Manchikanti L, Hirsch JA. Clinical management of radicular pain. Expert Rev Neurother 2015; 17:681-693.

36. Bogduk N, Aprill C, Derby R. Lumbar discogenic pain: State-of-the-art review. Pain Med 2013; 14:813-836.

37. Cohen SP, Larkin TM, Barna SA, Palmer WE, Hecht AC, Stojanovic MP. Lumbar discography: A comprehensive review of outcome studies, diagnostic accuracy, and principles. Reg Anesth Pain Med 2005; 30:163-183.

38. Hancock MJ, Maher CG, Latimer J, Spindler MF, McAuley JH, Laslett M, Bogduk N. Systematic review of tests to identify the disc, SIJ or facet joint as the source of low back pain. Eur Spine J 2007; 16:1539-1550.

39. Manchikanti L, Benyamin RM, Singh V, Falco FJE, Hameed H, Derby R, Wolfer LR, Helm II S, Calodney AK, Datta S,
Snook LT, Caraway DL, Hirsch JA, Cohen SP. An update of the systematic appraisal of the accuracy of utility of lumbar discography in chronic low back pain. Pain Physician 2013; 16:SE55-SE95.

40. Onyewu O, Manchikanti L, Falco FJE, Singh V, Geffert S, Helm II S, Cohen SP, Hirsch JA. An update of the appraisal of the accuracy and utility of cervical discography in chronic neck pain. Pain Physician 2012; 15:E777-E806.

41. Singh V, Manchikanti L, Onyewu O, Benyamin RM, Datta S, Geffert S, Parr AT, Falco FJE. An update of appraisal of accuracy of thoracic discography as a diagnostic test for chronic spinal pain. Pain Physician 2012; 15:E757-E776.

42. Willems P. Decision making in surgical treatment of chronic low back pain: The performance of prognostic tests to select patients for lumbar spinal fusion. Acta Orthop Suppl 2013; 84:1-35.

43. Sun $\mathrm{CH}$, Zheng $\mathrm{T}$, Chen $\mathrm{Z}$, Zheng $\mathrm{YH}$, Cao P, Zhang ZW, Lu J, Zou L. Retrospective and comparative analysis of therapy for degenerative chronic discogenic low back pain with end plate Modic changes with discography and intradiscal injection blockage. Zhonghua Yi Xue Za Zhi 2013; 93:1806-1810.

44. Peng BG. Pathophysiology, diagnosis, and treatment of discogenic low back pain. World J Orthop 2013; 4:42-52.

45. Willems PC, Staal JB, Walenkamp GH, de Bie RA. Spinal fusion for chronic low back pain: Systematic review on the accuracy of tests for patient selection. Spine J 2013; 13:99-109.

46. Eck JC, Sharan A, Resnick DK, Watters WC 3rd, Ghogawala Z, Dailey AT, Mummaneni PV, Groff MW, Wang JC, Choudhri TF, Dhall SS, Kaiser MG. Guideline update for the performance of fusion procedures for degenerative disease of the lumbar spine. Part 6: Discography for patient selection. J Neurosurg Spine 2014; 21:37-41.

47. Bokov A, Perlmutter O, Aleynik A, Rasteryaeva M, Mlyavykh S. The potential impact of various diagnostic strategies in cases of chronic pain syndromes associated with lumbar spine degeneration. J Pain Res 2013; 6:289-296.

48. Brayda-Bruno M, Tibiletti M, Ito K, Fairbank J, Galbusera F, Zerbi A, Roberts S, Wachtel E, Merkher Y, Sivan SS. Advances in the diagnosis of degenerated lumbar discs and their possible clinical application. Eur Spine J 2014; 23:S315-S323.

49. Bartynski WS, Dejohn LM, Rothfus WE, Gerszten PC. 'Progressive-onset' versus injury-associated discogenic low back pain: features of disc internal derangement in patients studied with provocation lumbar discography. Interv Neuroradiol 2013; 19:110-120.

50. Pang WW, Mok MS, Lin ML, Chang DP, Hwang $\mathrm{MH}$. Application of spinal pain mapping in the diagnosis of low back pain-analysis of 104 cases. Acta Anaesthesiol Sin 1998; 36:71-74.

51. Manchikanti L, Singh V, Pampati V, Damron K, Barnhill R, Beyer C, Cash K. Evaluation of the relative contributions of various structures in chronic low back pain. Pain Physician 2001; 4:308-316.

52. Schwarzer AC, Aprill CN, Derby R, Fortin J, Kine G, Bogduk N. The prevalence and clinical features of internal disc disruption in patients with chronic low back pain. Spine (Phila Pa 1976) 1995; 20:1878-1883.

53. Schwarzer AC, Aprill CN, Derby R, Fortin J, Kine G, Bogduk N. The relative contributions of the disc and zygapophysial joint in chronic low back pain. Spine (Phila Pa 1976) 1994; 19:801-806.

54. DePalma MJ, Ketchum JM, Saullo T. What is the source of chronic low back pain and does age play a role? Pain Med 2011; 12:224-233.

55. Verrills P, Nowesenitz G, Barnard A. Prevalence and characteristics of discogenic pain in tertiary practice: 223 consecutive cases utilizing lumbar discography. Pain Med 2015; 16:1490-1499.

56. Kim SM, Lee SH, Lee BR, Hwang JW. Analysis of the correlation among age, disc morphology, positive discography and prognosis in patients with chronic low back pain. Ann Rehabil Med 2015; 39:340-346.

57. Wolfer L, Derby R, Lee JE, Lee SH. Systematic review of lumbar provocation discography in asymptomatic subjects with a meta-analysis of false-positive rates. Pain Physician 2008; 11:513-538.

58. Yin W, Bogduk N. The nature of neck pain in a private pain clinic in the United States. Pain Med 2008; 9:196-203.

59. Bogduk N, Aprill C. On the nature of neck pain, discography and cervical zygapophysial joint blocks. Pain 1993; 54:213-217.

6o. Aprill C, Bogduk N. The prevalence of cervical zygapophyseal joint pain. A first approximation. Spine (Phila Pa 1976) 1992; 17:744-747.

61. Wood KB, Schellhas KP, Garvey TA, Aeppli D. Thoracic discography in healthy individuals. A controlled prospective study of magnetic resonance imaging 
and discography in asymptomatic and symptomatic individuals. Spine (Phila Pa 1976) 1999; 24:1548-1555.

62. Schellhas KP, Pollei SR, Dorwart RH. Thoracic discography. A safe and reliable technique. Spine (Phila Pa 1976) 1994; 19:2103-2109.

63. Laplante BL, Ketchum JM, Saullo TR, DePalma MJ. Multivariable analysis of the relationship between pain referral patterns and the source of chronic low back pain. Pain Physician 2012; 15:171-178.

64. Alamin TF, Kim MJ, Agarwal V. Provocative lumbar discography versus functional anesthetic discography: A comparison of the results of two different diagnostic techniques in 52 patients with chronic low back pain. Spine J 2011; 11:756-765.

65. Bogduk N. Low back pain. In: Clinical Anatomy of Lumbar Spine and Sacrum. 4th edition. Churchill Livingstone, New York, 2005, pp 183-216.

66. Peng B, Fu X, Pang X, Li D, Liu W, Gao $\mathrm{C}$, Yang $\mathrm{H}$. Prospective clinical study on natural history of discogenic low back pain at 4 years of follow-up. Pain Physician 2012; 15:523-532.

67. Kuslich SD, Ulstrom CL, Michael CJ. The tissue origin of low back pain and sciatica: A report of pain response to tissue stimulation during operation on the lumbar spine using local anesthesia. Orthop Clin North Am 1991; 22:181-187.

68. McCormick ZL, DeFrancesch F, Loomba V, Moradian M, Bathina R, Rappard G; Standards Division of the Spine Intervention Society. Diagnostic value, prognostic value, and safety of provocation discography. Pain Med 2018; 19:3-8.

69. Kallewaard JW, Geurts JW, Terheggen M, Terwiel C, Kessels A, van Kleef M, Willems PC. No transfer of pressure to adjacent discs during human low-pressure controlled discography: A prospective clinical study. Pain Med 2018; 19:29-39.

70. Liu J, Hao L, Zhang X, Shan Z, Li S, Fan S, Zhao F. Painful Schmorl's nodes treated by discography and discoblock. Eur Spine J 2018; 27:13-18.

71. Hebelka H, Hansson T. HIZ's relation to axial load and low back pain: Investigated with axial loaded MRI and pressure controlled discography. Eur Spine ] 2013; 22:734-739.

72. Putzier M, Streitparth F, Hartwig T, Perka CF, Hoff EK, Strube P. Can discoblock replace discography for identifying painful degenerated discs? Eur J Radiol 2013; 82:1463-1470.
73. Hebelka H, Brisby H, Hansson T. Comparison between pain at discography and morphological disc changes at axial loaded MRI in patients with low back pain. Eur Spine J 2014; 23:2075-2082.

74. Määttä JH, Karppinen Jl, Luk KD, Cheung KM, Samartzis D. Phenotype profiling of Modic changes of the lumbar spine and its association with other MRI phenotypes: A large-scale population-based study. Spine J 2015; 15:1933-1942.

75. Khan I, Hargunani R, Saifuddin A. The lumbar high-intensity zone: 20 years on. Clin Radiol 2014; 69:551-558.

76. Dongfeng R, Hou S, Wu W, Wang $\mathrm{H}$, Shang W, Tang J, Li Z, Lei G. The expression of tumor necrosis factor- $\square$ and CD68 in high-intensity zone of lumbar intervertebral disc on magnetic resonance image in the patients with low back pain. Spine (Phila Pa 1976) 2011; 36:E429-E433.

77. Wang Y, Videman T, Battié MC. Modic changes: Prevalence, distribution patterns, and association with age in white men. Spine J 2012; 12:411-416.

78. Coppes MH, Marani E, Thomeer RT, Groen GJ. Innervation of "painful" lumbar discs. Spine (Phila Pa 1976) 1997; 22:2342-2349.

79. Freemont AJ, Peacock TE, Goupille P, Hoyland JA, O'Brien J, Jayson MI. Nerve ingrowth into diseased intervertebral disc in chronic back pain. Lancet 1997; 350:178-181.

8o. Peng B, Hao J, Hou S, Wu W, Jiang D, Fu X, Yang Y. Possible pathogenesis of painful intervertebral disc degeneration. Spine (Phila Pa 1976) 2006; 31:560-566.

81. Peng B, Chen J, Kuang Z, Li D, Pang X, Zhang $X$. Expression and role of connective tissue growth factor in painful disc fibrosis and degeneration. Spine (Phila Pa 1976) 2009; 34:E178-E182.

82. Freemont AJ, Watkins A, Le Maitre C, Baird P, Jeziorska M, Knight MT, Ross ER, O'Brien JP, Hoyland JA. Nerve growth factor expression and innervation of the painful intervertebral disc. J Pathol 2002; 197:286-292.

83. Freemont AJ. The cellular pathobiology of the degenerate intervertebral disc and discogenic back pain. Rheumatology (Oxford) 2009; 48:5-10.

84. Wang Y, Videman T, Battié MC. ISSLS prize winner: Lumbar vertebral endplate lesions: Associations with disc degeneration and back pain history. Spine (Phila $\mathrm{Pa}$ 1976) 2012; 37:1490-1496.

85. Groen GJ, Baljet B, Drukker J. Nerves and nerve plexuses of the human vertebral column. Am J Anat 1990; 188:282-296.

86. Arndt J, Charles YP, Koebel C, Bogorin I, Steib JP. Bacteriology of degenerated lumbar intervertebral disks. J Spinal Disord Tech 2012; 25:E211-E216.

87. Fields AJ, Liebenberg EC, Lotz JC. Innervation of pathologies in the lumbar vertebral end plate and intervertebral disc. Spine J 2014; 14:513-521.

88. Keyes DC, Compere EL. The normal and pathological physiology of the nucleus pulposus of the intervertebral disc: An anatomical, clinical, and experimental study. J Bone Joint Surg Am 1932; 14:897-938.

89. Manchikanti L, Knezevic NN, Boswell MV, Kaye AD, Hirsch JA. Epidural injections for lumbar radiculopathy and spinal stenosis: A comparative systematic review and meta-analysis. Pain Physician 2016; 19:E365-E410.

90. Chou R, Hashimoto R, Friedly J, Fu Rochelle, Dana T, Sullivan S, Bougatsos C, Jarvik J. Pain Management Injection Therapies for Low Back Pain. Technology Assessment Report ESIBo813. (Prepared by the Pacific Northwest Evidence-based Practice Center under Contract No. HHSA 290-2012-00014I.) Rockville, MD: Agency for Healthcare Research and Quality; July 10, 2015.

www.cms.gov/medicare/coverage/determinationprocess/downloads/idg8ta.pdf

91. Manchikanti L, Benyamin RM, Falco FJ, Kaye AD, Hirsch JA. Do epidural injections provide short- and long-term relief for lumbar disc herniation? A systematic review. Clin Orthop Relat Res 2015; 473:1940-1956.

92. Manchikanti L, Nampiaparampil DE, Manchikanti KN, Falco FJE, Singh V, Benyamin RM, Kaye AD, Sehgal N, Soin A, Simopoulos TT, Bakshi S, Gharibo CG, Gilligan CJ, Hirsch JA. Comparison of the efficacy of saline, local anesthetics, and steroids in epidural and facet joint injections for the management of spinal pain: A systematic review of randomized controlled trials. Surg Neurol Int 2015; 6:S194-S235.

93. Kaye AD, Manchikanti L, Abdi S, Atluri S, Bakshi S, Benyamin R, Boswell MV, Buenaventura R, Candido KD, Cordner HJ, Datta S, Doulatram G, Gharibo CG, Grami V, Gupta S, Jha S, Kaplan ED, Malla Y, Mann DP, Nampiaparampil DE, Racz G, Raj P, Rana M, Sharma ML, Singh V, Soin A, Staats PS, Vallejo R, Wargo BW, Hirsch JA. Efficacy of epidural injections in managing chronic 
spinal pain: A best evidence synthesis. Pain Physician 2015; 18:E939-E1004.

94. Manchikanti L, Singh V, Pampati V, Falco FJE, Hirsch JA. Comparison of the efficacy of caudal, interlaminar, and transforaminal epidural injections in managing lumbar disc herniation: Is one method superior to the other? Korean J Pain 2015; 28:11-21.

95. Manchikanti L, Kaye AD, Manchikanti KN, Boswell MV, Pampati V, Hirsch JA. Efficacy of epidural injections in the treatment of lumbar central spinal stenosis: A systematic review. Anesth Pain Med 2015; 5:e23139.

96. Manchikanti L, Pampati V, Benyamin RM, Boswell MV. Analysis of efficacy differences between caudal and lumbar interlaminar epidural injections in chronic lumbar axial discogenic pain: Local anesthetic alone vs. local combined with steroids. Int J Med Sci 2015; 12:214-222.

97. Alemo S, Sayadipour A. Sources and patterns of pain in lumbar disc disease: Revisiting Francis Murphey's theory. Acta Neurochir (Wien) 2010; 152:1555-1558.

98. Manchikanti L, Nampiaparampil DE, Candido KD, Bakshi S, Grider JS, Falco FJE, Sehgal N, Hirsch JA. Do cervical epidural injections provide long-term relief in neck and upper extremity pain? A systematic review. Pain Physician 2015; 18:39-60.

99. Manchikanti L, Staats PS, Nampiaparampil DE, Hirsch JA. What is the role of epidural injections in the treatment of lumbar discogenic pain: A systematic review of comparative analysis with fusion and disc arthroplasty. Korean J Pain 2015; 28:75-87.

100. Mixter WJ, Barr JS. Rupture of the intervertebral disc with involvement of the spinal canal. N Engl J Med 1934; 211:210-215.

101. Willems PC. Provocative diskography: Safety and predictive value in the outcome of spinal fusion or pain intervention for chronic low-back pain.] Pain Res 2014; 7:699-705.

102. Cheung KM, Karppinen J, Chan D, Ho DW, Song YQ, Sham P, Cheah KS, Leong JC, Luk KD. Prevalence and pattern of lumbar magnetic resonance imaging changes in a population study of one thousand forty-three individuals. Spine (Phila Pa 1976) 2009; 34:934-940.

103. Byun WM, Ahn SH, Ahn MW. Significance of perianular enhancement associated with anular tears on magnetic resonance imagings in diagnosis of radiculopathy. Spine (Phila Pa 1976) 2008; 33:2440-2443.

104. Chen JY, Ding Y, Lv RY, Liu QY, Huang JB, Yang ZH, Liu SL. Correlation between $M R$ imaging and discography with provocative concordant pain in patients with low back pain. Clin J Pain 2011; 27:125-130.

105. Moneta GB, Videman T, Kaivanto $\mathrm{K}$ Aprill C, Spivey M, Vanharanta H, Sachs BL, Guyer RD, Hochschuler SH, Raschbaum RF, Mooney V. Reported pain during lumbar discography as a function of anular ruptures and disc degeneration. A re-analysis of 833 discograms. Spine (Phila Pa 1976) 1994; 19:1968-1974.

106. Kim HG, Shin DA, Kim HI, Yoo EA, Shin DG, Lee JO. Clinical and radiological findings of discogenic low back pain confirmed by automated pressure-controlled discography. J Korean Neurosurg Soc 2009; 46:333-339.

107. Thompson KJ, Dagher AP, Eckel TS, Clark M, Reinig JW. Modic changes on MR images as studied with provocative diskography: Clinical relevance---a retrospective study of 2457 disks. Radiology 2009; 250:849-855.

108. Block AR, Vanharanta H, Ohnmeiss DD, Guyer RD. Discographic pain report. Influence of psychological factors. Spine (Phila Pa 1976) 1996; 21:334-338.

109. Milette PC, Fontaine S, Lepanto L, Cardinal E, Breton G. Differentiating lumbar disc protrusions, disc bulges, and discs with normal contour but abnormal signal intensity. Magnetic resonance imaging with discographic correlations. Spine (Phila Pa 1976) 1999; 24:44-53.

110. Bokov A, Skorodumov A, Isrelov A, Stupak Y, Kukarin A. Differential treatment of nerve root compression pain caused by lumbar disc herniation applying nucleoplasty. Pain Physician 2010; 13:469-480.

111. Laslett M, Oberg B, Aprill CN, McDonald B. Centralization as a predictor of provocation discography results in chronic low back pain, and the influence of disability and distress on diagnostic power. Spine J 2005; 5:370-380.

112. Laslett M, April CN, McDonald B, Oberg B. Clinical predictors of lumbar provocation discography: A study of clinical predictors of lumbar provocation discography. Eur Spine J 2006; 15:1473-1484.

113. Yu Y, Liu W, Song D, Guo Q, Jia L. Diagnosis of discogenic low back pain in patients with probable symptoms but negative discography. Arch Orthop Trau- ma Surg 2012; 132:627-632.

114. Zhang JD, Xia Q, Hu YC, Miao J, Feng QJ. Analysis of the relationship between morphology of intervertebral disc and some correlated factors following discography in patients with chronic low back pain. Orthop Surg 2009; 1:47-51.

115. Lam KS, Carlin D, Mulholland RC. Lumbar disc high-intensity zone: The value and significance of provocative discography in the determination of the discogenic pain source. Eur Spine J 2000; 9:36-41.

116. Wang HD, Hou SX, Wang XN, Li ZZ, Wu WW. [Correlation between high intensity zone on MRI and positive pain response on lumbar discography in the diagnosis of discogenic low back pain]. Zhonghua Wai Ke Za Zhi 2008; 46:973-976.

117. Hoppe S, Quirbach S, Mamisch TC, Krause FG, Werlen S, Benneker LM. Axial $\mathrm{T}_{2}$ * mapping in intervertebral discs: $\mathrm{A}$ new technique for assessment of intervertebral disc degeneration. Eur Radiol 2012; 22:2013-2019.

118. Livshits G, Popham M, Malkin I, Sambrook PN, Macgregor AJ, Spector T, Williams FM. Lumbar disc degeneration and genetic factors are the main risk factors for low back pain in women: The UK twin spine study. Ann Rheum Dis 2011; 70:1740-1745.

119. Inoue N, Espinoza Orías AA. Biomechanics of intervertebral disk degeneration. Orthop Clin North Am 2011; 42:487499, vii.

120. Ohtori S, Inoue G, Miyagi M, Takahashi K. Pathomechanisms of discogenic low back pain in humans and animal models. Spine J 2015; 15:1347-1355.

121. Merskey H, Bogduk N. Classification of Chronic Pain. Descriptions of Chronic Pain Syndromes and Definition of Pain Terms. 2nd ed. IASP Press, Seattle, 1994, pp 180-181.

122. Derby R, Lee JE, Lee SH. Analgesic discography: Effect of adding a local anesthetic to routine lumbar provocation discography. Pain Med 2010; 11:1335-1342.

123. Choi WS, Shin DA, Kim HI, Lee SH, Derby R, Lee SH, Kim HJ. Toward more useful pressure-controlled discography: In vitro evaluation of injection speed, sensor location, and tube length. Pain Med 2011; 12:36-44.

124. Derby R, Lee SH, Lee JE, Lee SH. Comparison of pressure-controlled provocation discography using automated versus manual syringe pump manometry 
in patients with chronic low back pain. Pain Med 2011; 12:18-26.

125. Provenzano DA. Diagnostic discography: What is the clinical utility? Curr Pain Headache Rep 2012; 16:26-34.

126. Derby R, Lee SH, Kim BJ, Chen Y, Aprill C, Bogduk N. Pressure-controlled lumbar discography in volunteers with low back pain symptoms. Pain Med 2005; 6:213-221.

127. Derby R, Kim BJ, Lee SH, Chen Y, Seo $\mathrm{KS}$, Aprill C. Comparison of discographic findings in asymptomatic subject discs and negative discs of chronic low back pain patients: Can discography distinguish asymptomatic discs among morphologically abnormal discs? Spine ] 2005; 5:389-394.

128. Wang Y, Videman T, Battié MC. Lumbar vertebral endplate lesions: Prevalence, classification, and association with age. Spine (Phila Pa 1976) 2012; 37:1432-1439.

129. Derby R, Kim BJ, Chen Y, Seo KS, Lee SH. The relation between annular disruption on computed tomography scan and pressure-controlled diskography. Arch Phys Med Rehabil 2005; 86:1534-1538.

130. Derby R, Howard MW, Grant JM, Lettice JJ, Van Peteghem PK, Ryan DP. The ability of pressure-controlled discography to predict surgical and nonsurgical outcomes. Spine (Phila Pa 1976) 1999; 24:364-371.

131. Carragee EJ, Chen Y, Tanner CM, Hayward C, Rossi M, Hagle C. Can discography cause long-term back symptoms in previously asymptomatic subjects? Spine (Phila Pa 1976) 2000; 25:1803-1808.

132. Carragee EJ, Barcohana B, Alamin T, van den Haak E. Prospective controlled study of the development of lower back pain in previously asymptomatic subjects undergoing experimental discography. Spine (Phila Pa 1976) 2004; 29:1112-1117.

133. Carragee EJ, Alamin TF, Miller J, Grafe M. Provocative discography in volunteer subjects with mild persistent low back pain. Spine J 2002; 2:25-34.

134. Carragee EJ, Chen Y, Tanner CM, Truong T, Lau E, Brito JL. Provocative discography in patients after limited lumbar discectomy: A controlled, randomized study of pain response in symptomatic and asymptomatic subjects. Spine (Phila $\mathrm{Pa}$ 1976) 2000; 25:3065-3071.

135. Carragee EJ, Tanner CM, Yang B, Brito JL, Truong T. False-positive findings on lumbar discography. Reliability of subjective concordance assessment during provocative disc injection. Spine (Phila Pa 1976) 1999; 24:2542-2547.

136. Carragee EJ, Tanner CM, Khurana S, Hayward C, Welsh J, Date E, Truong T, Rossi M, Hagle C. The rates of falsepositive lumbar discography in select patients without low back symptoms. Spine (Phila Pa 1976) 2000; 25:1373-1381.

137. Carragee EJ, Paragioudakis SJ, Khurana S. 2000 Volvo Award winner in clinical studies: Lumbar high-intensity zone and discography in subjects without low back problems. Spine (Phila Pa 1976) 2000; 25:2987-2992.

138. Carragee EJ, Alamin TF, Miller JL, Carragee JM. Discographic, MRI, and psychosocial determinants of low back pain disability and remission: A prospective study in subjects with benign persistent back pain. Spine J 2005; 5:24-35.

139. Carragee EJ, Alamin TF, Carragee JM. Low-pressure positive discography in subjects asymptomatic of significant low back pain illness. Spine (Phila Pa 1976) 2006; 31:505-509.

140. Carragee EJ, Lincoln T, Parmar VS, Ala$\min$ T. A gold standard evaluation of the "discogenic pain" diagnosis as determined by provocative discography. Spine (Phila Pa 1976) 2006; 31:2115-2123.

141. New Questions About the Safety of a Widely Employed Diagnostic Test. BackLetter February 2012; 27:13, 19-21.

142. Madan S, Gundanna M, Harley JM, Boeree NR, Sampson M. Does provocative discography screening of discogenic back pain improve surgical outcome? J Spinal Disord Tech 2002; 15:245-251.

143. Kang $\mathrm{CH}$, Kim $\mathrm{YH}$, Lee $\mathrm{SH}$, Derby $\mathrm{R}$, Kim JH, Chung KB, Sung DJ. Can magnetic resonance imaging accurately predict concordant pain provocation during provocative disc injection? Skeletal Radiol 2009; 38:877-885.

144. Derby R, Baker R, Wolfer L, DePalma M. Analgesic discography: Can analgesic testing identify a painful disc? SpineLine 2008; Nov/Dec:17-24.

145. Cohen SP, Larkin T, Fant GV, Oberfoell $R$, Stojanovic M. Does needle insertion site affect diskography results? A retrospective analysis. Spine (Phila Pa 1976) 2002; 27:2279-2283.

146. Derby R, Lee SH, Chen Y, Kim BJ, Lee $\mathrm{CH}$, Hong YK, Lee JE, Seo KS. The influence of psychologic factors on diskography in patients with chronic axial low back pain. Arch Phys Med Rehabil 2008; 89:1300-1304

147. Derby R, Lettice JJ, Kula TA, Lee SH, Seo
KS, Kim BJ. Single-level lumbar fusion in chronic discogenic low-back pain: Psychological and emotional status as a predictor of outcome measured using the 36-item Short Form. J Neurosurg Spine 2005; 3:255-261.

148. Seo KS, Derby R, Date ES, Lee SH, Kim $\mathrm{BJ}$, Lee $\mathrm{CH}$. In vitro measurement of pressure differences using manometry at various injection speeds during discography. Spine ] 2007; 7:68-73.

149. Lucas N, Macaskill P, Irwig L, Moran R, Bogduk N. Reliability of physical examination for diagnosis of myofascial trigger points: A systematic review of the literature. Clin J Pain 2009; 25:80-89.

150. Lucas NP, Macaskill P, Irwig L, Bogduk $\mathrm{N}$. The development of a quality appraisal tool for studies of diagnostic reliability (QAREL). J Clin Epidemiol 2010; 63:854-861.

151. Bossuyt PM, Reitsma JB, Bruns DE, Gatsonis CA, Glasziou PP, Irwig LM, Lijmer JG, Moher D, Rennie D, de Vet HC; Standards for Reporting of Diagnostic Accuracy. Towards complete and accurate reporting of studies of diagnostic accuracy: The STARD Initiative. Ann Intern Med 2003; 138:40-44.

152. Whiting P, Rutjes A, Reitsma J, Bossuyt P, Kleijnen J. The Development of QUADAS: A tools for the quality assessment of studies of diagnostic accuracy included in systematic reviews. BMC Med Res Methodol 2003; 3:25.

153. Manchikanti L, Falco FJE, Benyamin RM, Kaye AD, Boswell MV, Hirsch JA. A modified approach to grading of evidence. Pain Physician 2014; 17:E319-E325.

154. Manchikanti L, Singh V, Pampati VS, Fellows B, Beyer C, Damron K, Cash KA. Provocative discography in low back pain patients with or without somatization disorder: A randomized prospective evaluation. Pain Physician 2001; 4:227-239.

155. Shin DA, Kim HI, Jung JH, Shin DG, Lee JO. Diagnostic relevance of pressurecontrolled discography. J Korean Med Sci 2006; 21:911-916.

156. Walsh TR, Weinstein JN, Spratt KF, Lehmann TR, Aprill C, Sayre H. Lumbar discography in normal subjects. A controlled, prospective study. J Bone Joint Surg Am 1990; 72:1081-1088.

157. Derby R, Aprill CN, Lee JE, Depalma MJ, Baker RM. Comparison of four different analgesic discogram protocols comparing the incidence of reported pain relief following local anesthetic injection into concordantly painful lumbar interverte- 
bral discs. Pain Med 2012; 13:1547-1553.

158. Oikawa Y, Ohtori S, Koshi T, Takaso M, Inoue G, Orita S, Eguchi Y, Ochiai N, Kishida S, Kuniyoshi K, Nakamura J, Aoki Y, Ishikawa T, Miyagi M, Arai G, Kamoda H, Suzuki M, Sainoh T, Toyone T, Takahashi K. Lumbar disc degeneration induces persistent groin pain. Spine (Phila Pa 1976) 2012; 37:114-118.

159. Holt EP. The question of lumbar discography. J Bone Joint Surg Am 1958; 50:720-726.

160. Massie WK, Steven DB. A critical evaluation of discography. J Bone Joint Surg Am 1967; 49A:1243-1244.

161. O'Neill CW. Commentary: Diagnostic tests for chronic low back pain - a dismal science. Spine ] 2013; 13:113-115.

162. Blumenthal SL, Ohnmeiss DD, Guyer $\mathrm{RD}$, Hochschuler SH. Prospective study evaluating total disc replacement: Preliminary results. J Spinal Disord Technol 2003; 16:450-454.

163. Moore KR, Pinto MR, Butler LM. Degenerative disc disease treated with combined anterior and posterior arthrodesis and posterior instrumentation. Spine (Phila Pa 1976) 2002; 27:1680-1686.

164. Colhoun E, McCall IW, Williams L, Cassar Pullicino VN. Provocation discography as a guide to planning operations on the spine. ] Bone Joint Surg $\mathrm{Br} 1988$; 70:267-271.

165. Gokaslan ZL, Desai A. Utility of provocative discography. World Neurosurg 2014; 82:638-639.

166. Ohtori S, Koshi T, Yamashita M, Yamauchi K, Inoue G, Suzuki M, Orita S, Eguchi Y, Ochiai N, Kishida S, Takaso M, Kuniyoshi K, Aoki Y, Ishikawa T, Arai G, Miyagi M, Kamoda $\mathrm{H}$, Suzuki $\mathrm{M}, \mathrm{Na}-$ kamura J, Toyone T, Takahashi K. Surgical versus nonsurgical treatment of selected patients with discogenic low back pain: A small-sized randomized trial. Spine (Phila Pa 1976) 2011; 36:347-354.

167. Berg S, Isberg B, Josephson A, Fällman $M$. The impact of discography on the surgical decision in patients with chronic low back pain. Spine ] 2012; 12:283-291.

168. Parker LM, Murrell SE, Boden SD, Horton WC. The outcome of posterolateral fusion in highly selected patients with discogenic low back pain. Spine (Phila Pa 1976) 1996; 21:1909-1917.

169. Tsou PM, Yeung CA, Yeung AT. Posterolateral transforaminal selective endoscopic discectomy and thermal annuloplasty for chronic lumbar discogenic pain: A minimal access visualized intradiscal surgical procedure. Spine ] 2004; 4:564-573.

170. Gill K, Blumenthal SL. Functional results after anterior lumbar fusion at $\mathrm{L}_{5}-\mathrm{S} 1$ in patients with normal and abnormal MRI scans. Spine (Phila Pa 1976) 1992; 17:940-942.

171. Wetzel FT, LaRocca SH, Lowery GL, Aprill CN. The treatment of lumbar spinal pain syndromes diagnosed by discography. Lumbar arthrodesis. Spine (Phila Pa 1976) 1994; 19:792-800.

172. Willems PC, Elmans L, Anderson PG, van der Schaaf DB, de Kleuver M. Provocative discography and lumbar fusion: Is preoperative assessment of adjacent discs useful? Spine (Phila Pa 1976) 2007; 32:1094-1099.

173. Knox BD, Chapman TM. Anterior lumbar interbody fusion for discogram concordant pain. J Spinal Disord 1993; 6:242-244.

174. Vamvanij V, Fredrickson BE, Thorpe JM, Stadnick ME, Yuan HA. Surgical treatment of internal disc disruption: An outcome study of four fusion techniques. J Spinal Disord 1998; 11:375-382.

175. Helm II S, Simopoulos TT, Stojanovic M, Abdi S, El Terany MA. Effectiveness of thermal annular procedures in treating discogenic low back pain. Pain Physician 2017; 20:447-470.

176. Shim CS, Lee SH, Park CW, Choi WC Choi G, Choi WG, Lim SR, Lee HY. Partial disc replacement with the PDN prosthetic disc nucleus device. J Spina Disord Technol 2003; 16:324-330.

177. van Ooij A, Oner FC, Verbout AJ. Complications of artificial disc replacement: A report of 27 patients with the SB Charite disc. J Spinal Disord Technol 2003; 16:369-383.

178. McAfee PC, Fedder IL, Saiedy S, Shucosky EM, Cunningham BW. SB Charite disc replacement: Report of 60 prospective randomized cases in a U.S. center. J Spinal Disord Technol 2003; 16:424-433.

179. Appleby D, Andersson G, Totta M. Metaanalysis of the efficacy and safety of intradiscal electrothermal therapy (IDET). Pain Med 2006; 4:308-316.

180. Zeegers WS, Bohnen LM, Laaper M, Verhaegen MJ. Artificial disc replacement with the modular type SB Charite III: 2-year results in 50 prospectively studied patients. Eur Spine J 1999; 8:210-217.

181. Hochschuler SH, Ohnmeiss DD, Guyer
RD, Blumenthal SL. Artificial disc: Preliminary results of a prospective study in the United States. Eur Spine J 2002; 11:S106-S110.

182. Enker P, Steffee A, McMillin C, Keppler L, Biscup R, Miller S. Artificial disc replacement: Preliminary report with a 3-year minimum follow-up. Spine (Phila Pa 1976) 1993; 18:1061-1070.

183. Bogduk N. Lumbar disc stimulation (provocation discography). In: Practice Guidelines for Spinal Diagnostic and Treatment Procedures. 1st edition. International Spine Intervention Society, Seattle, 2004, pp 20-46.

184. Kapural L, Hayek S, Malak O, Arrigain S, Mekhail N. Intradiscal thermal annuloplasty versus intradiscal radiofrequency ablation for the treatment of discogenic pain: A prospective matched control trial. Pain Med 2005; 6:425-431.

185. Zheng Y, Liew SM, Simmons ED. Value of magnetic resonance imaging and discography in determining the level of cervical discectomy and fusion. Spine (Phila Pa 1976) 2004; 29:2140-2145.

186. Motimaya A, Arici M, George D, Ramsby $G$. Diagnostic value of cervical discography in the management of cervical discogenic pain. Conn Med 2000; 64:395-398.

187. Palit M, Schofferman J, Goldthwaite $\mathrm{N}$, Reynolds J, Kerner M, Keaney D, Lawrence-Miyasaki L. Anterior discectomy and fusion for the management of neck pain. Spine (Phila Pa 1976) 1999; 24:2224-2228.

188. Siebenrock KA, Aebi M. Cervical discography in discogenic pain syndrome and its predictive value for cervical fusion. Arch Orthop Trauma Surg 1994; 113:199-203.

189. Hubach PC. A prospective study of anterior cervical spondylodesis in intervertebral disc disorders. Eur Spine J 1994; 3:209-213.

190. Connor PM, Darden BV II. Cervical discography complications and clinical efficacy. Spine (Phila Pa 1976) 1993; 18:2035-2038.

191. Siebenrock KA, Aebi M. The value of diskography in disk-related pain syndrome of the cervical spine for evaluation of indications for spondylodesis. Z Orthop Ihre Grenzgeb 1993; 131:220-224.

192. Osler GE. Cervical analgesic discography. A test for diagnosis of the painful disc syndrome. S Afr Med ] 1987; 71:363.

193. Whitecloud TS 3rd, Seago RA. Cervical 
discogenic syndrome. Results of operative intervention in patients with positive discography. Spine (Phila Pa 1976) 1987; 2:313-316.

194. Kikuchi S, Macnab I, Moreau P. Localisation of the level of symptomatic cervical disc degeneration. J Bone Joint Surg $\mathrm{Br}$ 1981; 63-B:272-277.

195. Simmons EH, Segil CM. An evaluation of discography in the localization of symptomatic levels in discogenic disease of the spine. Clin Orthop Relat Res 1975; 108:57-69.

196. Chirls M. Discography, myelography, and interbody fusions for cervical syndromes. J Med Soc N J 1970; 67:530-532.

197. Simmons EH, Bhalla SK, Butt WP. Anterior cervical discectomy and fusion: A clinical and biomechanical study with eight year follow up with a note on discography technique and interpretation of results. J Bone Joint Surg 1969; 51B:225-237.

198. Schaerer JP. Anterior cervical disc removal and fusion. Schweiz Arch Neurol Neurochir Psychiatr 1968; 102:331-344.

199. Roth DA. Cervical analgesic discography. A new test for the definitive diagnosis of the painful disc syndrome. JAMA 1976; 235:1713-1714.

200. Riley LH Jr, Robinson RA, Johnson KA, Walker AE. The results of anterior interbody fusion of the cervical spine. Review of 93 consecutive cases. J Neurosurg 1969; 30:127-133.

201. Klafta LA Jr., Collis JS Jr. An analysis of discography with surgical verification. J Neurosurg 1969; 30:38-41.

202. Williams JL, Allen MB, Harkess JW. Late results of cervical discectomy and interbody fusion: Some factors influencing the results. J Bone Joint Surg Am 1968; 50:277-286.

203. Cohen SP, Hurley RW. The ability of diagnostic spinal injections to predict surgical outcomes. Anesth Analg 2007; 105:1756-1775.

204. Manchikanti L, Cash KA, McManus CD, Pampati V. Fluoroscopic caudal epidural injections in managing chronic axial low back pain without disc herniation, radiculitis or facet joint pain. J Pain Res 2012; 5:381-390.

205. Manchikanti L, Cash KA, McManus CD, Pampati V, Benyamin RM. A randomized, double-blind, active-controlled trial of fluoroscopic lumbar interlaminar epidural injections in chronic axial or discogenic low back pain: Results of a 2-year follow-up. Pain Physician 2013; 16:-E491-E504.

206. Manchikanti L, Cash KA, McManus CD, Pampati V, Benyamin RM. Thoracic interlaminar epidural injections in managing chronic thoracic pain: A randomized, double-blind, controlled trial with a 2-year follow-up. Pain Physician 2014; 17:E327-E338.

207. Manchikanti L, Cash KA, Pampati V, Malla Y. Two-year follow-up results of fluoroscopic cervical epidural injections in chronic axial or discogenic neck pain: A randomized, double-blind, controlled trial. Int J Med Sci 2014; 11:309-320.

208. Manchikanti L, Singh V, Rivera JJ, Pampati $V$, Beyer CD, Damron KS, Barnhill RC. Effectiveness of caudal epidural injections in discogram positive and negative chronic low back pain. Pain Physician 2002; 5:18-29.

209. Lee JW, Shin HI, Park SY, Lee GY, Kang HS. Therapeutic trial of fluoroscopic interlaminar epidural steroid injection for axial low back pain: Effectiveness and outcome predictors. AJNR Am ] Neuroradiol 2010; 31:1817-1823.

210. Cuellar JM, Stauff MP, Herzog RJ, Carrino JA, Baker GA, Carragee EJ. Does provocative discography cause clinically important injury to the lumbar intervertebral disc? A 10-year matched cohort study. Spine ] 2016; 16:273-280.

211. Gruber HE, Rhyne AL 3rd, Hansen KJ, Phillips RC, Hoelscher GL, Ingram JA, Norton HJ, Hanley EN Jr. Deleterious effects of discography radiocontrast solution on human annulus cell in vitro: Changes in cell viability, proliferation, and apoptosis in exposed cells. Spine J 2012; 12:329-335.

212. Carragee EJ, Don AS, Hurwitz EL, Cuellar JM, Carrino JA, Herzog R. 2009 ISSLS Prize Winner: Does discography cause accelerated progression of degeneration changes in the lumbar disc: A tenyear matched cohort study. Spine (Phila $\mathrm{Pa} \mathrm{1976)} \mathrm{2009;} \mathrm{34:2338-2345.}$

213. Carragee EJ, Barcohana B, Alamin T, van den Haak E. Prospective controlled study of the development of lower back pain in previously asymptomatic subjects undergoing experimental discography. Spine (Phila Pa 1976) 2004; 29:1112-1117.

214. Carragee EJ, Alamin TF. Discography. A review. Spine ] 2001; 1:364-372.

215. Carragee EJ, Chen Y, Tanner CM, Hayward C, Rossi M, Hagle C. Can discog- raphy cause long-term back symptoms in previously asymptomatic subjects? Spine (Phila Pa 1976) 2000; 25:1803-1808.

216. Alamin T, Malek F, Carragee E, Kim MJ. The functional anaesthetic discogram: Description of a novel diagnostic technique and report of 3 cases. SAS J 2008; 2:107-113.

217. American College of Occupational and Environmental Medicine (ACOEM) Low back disorders. In: Occupational Medicine Practice Guidelines: Evaluation and Management of Common Health Problems and Functional Recovery of Workers. Second Edition. American College of Occupational and Environmental Medicine Press, Elk Grove Village, 2007.

218. American College of Occupational and Environmental Medicine (ACOEM) Chronic pain. In: Occupational Medicine Practice Guidelines: Evaluation and Management of Common Health Problems and Functional Recovery of Workers. Second Edition. American College of Occupational and Environmental Medicine Press, Elk Grove Village, 2008.

219. Chou R, Baisden J, Carragee EJ, Resnick DK, Shaffer WO, Loeser JD. Surgery for low back pain: A review of the evidence for an American Pain Society Clinical Practice Guideline. Spine (Phila Pa 1976) 2009; 34:1094-1109.

220. Chou R, Atlas SJ, Stanos SP, Rosenquist RW. Nonsurgical interventional therapies for low back pain: A review of the evidence for an American Pain Society clinical practice guideline. Spine (Phila Pa 1976) 2009; 34:1078-1093.

221. Manchikanti L, Singh V, Derby R, Schultz DM, Benyamin RM, Prager JP, Hirsch JA. Reassessment of evidence synthesis of occupational medicine practice guidelines for interventional pain management. Pain Physician 2008; 11:393-482.

222. Department of Health and Human Services (DHHS). Centers for Medicare \& Medicaid Services (CMS). CMS Manual System. Pub. 100-04 Medicare Claims Processing. Transmittal 1646. Noncovered decisions for Thermal Intradiscal Procedures (TIPs). Effective Date 09/29/2008.

223. Chou R, Huffman L. Guideline for the Evaluation and Management of Low Back Pain: Evidence Review. American Pain Society, Glenview, IL, 2009.

224. Chee AV, Ren J, Lenart BA, Chen EY, Zhang Y, An HS. Cytotoxicity of local anesthetics and nonionic contrast agents 
on bovine intervertebral disc cells cultured in a three-dimensional culture system. Spine J 2014; 14:491-498.

225. Eder C, Pinsger A, Schildboeck S, Falkner E, Becker P, Ogon M. Influence of intradiscal medication on nucleus pulposus cells. Spine ] 2013; 13:1556-1562.

226. Cuellar JM, Golish SR, Reuter MW, Cuellar JM, Golish SR, Reuter MW. Cytokine evaluation in individuals with low back pain using discographic lavage. Spine J 2010; 10:212-218.

227. Shah RV, Everett C, McKenzie-Brown A, Sehgal N. Discography as a diagnostic test for spinal pain: A systematic and narrative review. Pain Physician 2005; 8:187-209.

228. Jensen MC, Brant-Zawadzki MN, Obuchowski N, Ross JS, Modic MT. Magnetic resonance imaging of the lumbar spine in people without back pain. $N$ Engl ] Med 1994; 331:69-73.

229. Boden SD, Davis DO, Dina TS, Patronas NJ, Wiesel SW. Abnormal magneticresonance scans of the lumbar spine in asymptomatic subjects. A prospective investigation. J Bone Joint Surg Am 1990; 72:403-408.
230. Levi D, Horn S, Tyszko S, Levin J, HechtLeavitt C, Walko E. Intradiscal plateletrich plasma injection for chronic discogenic low back pain: Preliminary results from a prospective trial. Pain Med 2016; 17:1010-1022.

231. Lee $\mathrm{SH}$, Derby R, Sul D, Hong YK, Ha $\mathrm{KW}$, Suh D, Lee $\mathrm{SH}$, Yoon HS, Yoo SH, Lee SJ, Park HJ, Jung YJ, Lee JE, Kim NH. Effectiveness of a new navigable percutaneous disc decompression device (L'DISQ) in patients with lumbar discogenic pain. Pain Med 2015; 16:266-273. 